\title{
ENSINANDO ANTROPÓLOGOS A DESENHAR: UMA EXPERIÊNCIA DIDÁTICA E DE PESQUISA
}

Karina Kuschnir ${ }^{1}$

UFRJ, Rio de Janeiro, RJ, Brasil

\begin{abstract}
Apresento neste trabalho os resultados de uma experiência de ensino chamada "Laboratório de Antropologia e Desenho", que propóe o desenho como ferramenta central para a pesquisa etnográfica. Alunos sem formação prévia na área foram apresentados ao ato de desenhar como uma forma de se conbecer o mundo. Através de oficinas práticas, as convençôes em torno do desenho acabaram desconstruidas para, em seu lugar, reencontrarmos novas formas narrativas capazes de evocar graficamente ideias, encontros, diálogos, observações e percepções sobre a vida social. Por meio de exercícios, tratamos da formação dos pesquisadores aos dispositivos de diálogo e troca com o universo pesquisado, passando pelo processo de registro dos dados e da divulgação dos resultados. A experiência partiu da sala de aula para, posteriormente, explorar espaços na cidade do Rio de Janeiro, tendo como pano de fundo o desafio de compreender a cidade e os múltiplos pontos de vista que se enfrentam no espaço urbano. Na análise do material produzido buscamos enfrentar questões centrais para a prática da pesquisa antropológica, explorando as consequências, perguntas e soluções que emergem do ato de se ensinar a desenhar e construir narrativas gráficas no (e sobre o) trabalho de campo.
\end{abstract}

Palavras-chave: antropologia, desenho, ensino, etnografia

1 Professora adjunta do Departamento de Antropologia Cultural (DAC) do Instituto de Filosofia e Ciências Sociais (IFCS) da Universidade Federal do Rio de Janeiro (UFRJ), onde coordena o Laboratório de Antropologia Urbana (LAU, www.lau-ufrj.blogspot.com). É bolsista de produtividade em pesquisa do CNPq e autora, entre outros, dos livros "Antropologia da Política" e "Pesquisas urbanas: desafios do trabalho antropológico" (co-org. com Gilberto Velho). Desenvolve os projetos "História audiovisual das Ciências Sociais nos países da CPLP" (CNPq/ CPLP, www.cpdoc.fgv.br/cientistassociais), "Desenhando cidades: estudos etnográficos no universo de desenhadores urbanos" (CNPq/Faperj) e "Laboratório de Antropologia e Design" (Faperj, parceria IFCS/Esdi-UERJ). Contato: karinakuschnir@gmail.com 


\section{EnSINANDO ANTROPÓlogos A DESENHAR}

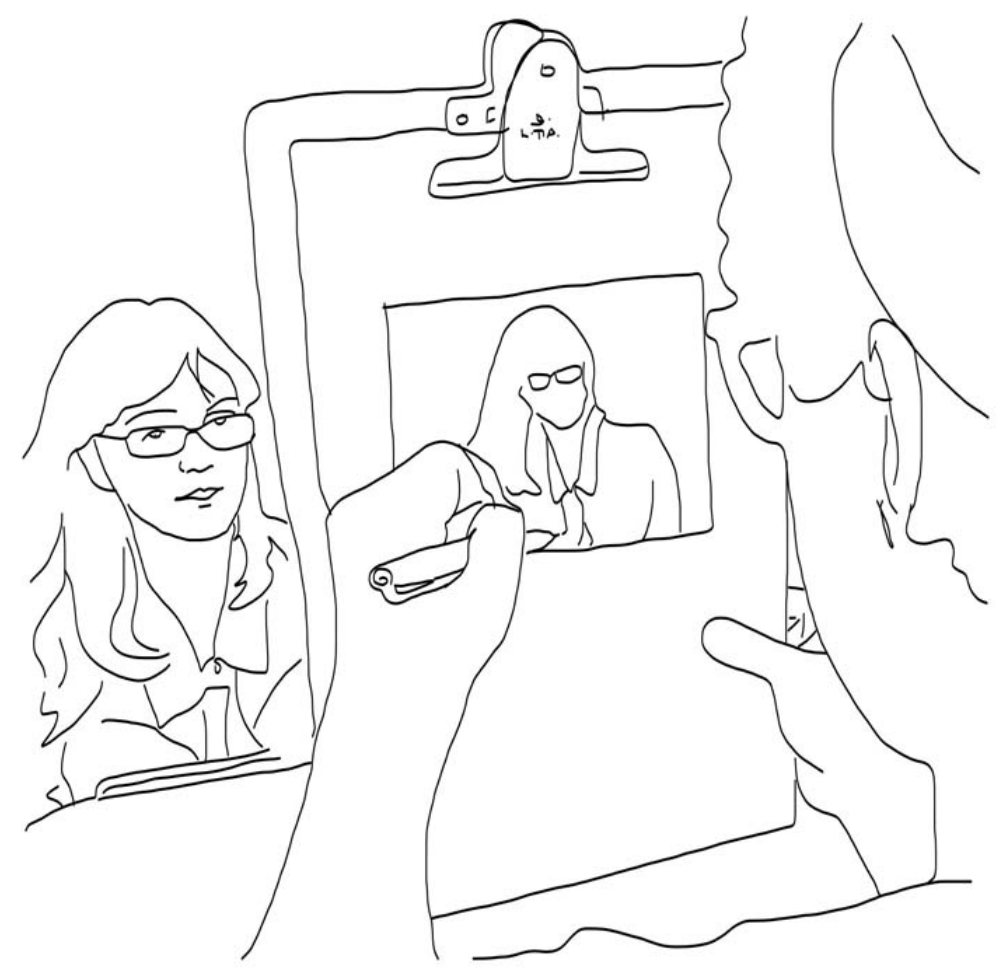

Será que desenhar pode contribuir para a produção de conhecimento antropológico? E será que um aluno de graduação em Ciências Sociais pode aprender o suficiente sobre desenho para utilizá-lo com bom rendimento num trabalho de curso de antropologia? Minha resposta neste artigo será duplamente "sim". Ou melhor, nossa resposta será um duplo "sim", pois este texto é sobre uma experiência coletiva. ${ }^{2}$

Em abril de 2013 ofereci pela primeira vez a disciplina eletiva "Laboratório de Antropologia e Desenho" a cerca de trinta alunos de bacharelado em Ciências Sociais do IFCS/UFRJ. ${ }^{3}$ A criação desse curso foi uma necessidade da pesquisa que venho desenvolvendo intitulada "Desenhando cidades: estudos etnográficos no Rio de Janeiro". Não que eu tenha planejado esse desdobramento. Em 2011, quando escrevi o projeto para o CNPq, acreditava que dali a pouco haveria no Rio de Janeiro grupos de pessoas interessadas em desenhar a cidade, simpatizantes

2 Agradeço ao CNPq, à Faperj e à UFRJ pelos financiamentos que apoiaram a realização da pesquisa relatada neste artigo. Este trabalho é fruto também da intensa colaboração dos bolsistas Pedro Ferraz Gama (Faperj), Carlos Henrique Sousa (CNPq) e Vinícius de Moraes Azevedo (CNPq/UFRJ), integrantes do Laboratório de Antropologia Urbana (LAU) no primeiro semestre de 2013, a quem agradeço sinceramente. Também não poderia deixar de agradecer aos colaboradores que foram fundamentais para o planejamento e realização deste projeto: Elisa Kuschnir, Celina Kuschnir, Andréa Barbosa, Moana Van de Beuque, Claudius Ceccon, Nazaré Saluto, Els Lagrou, Zoy Anastassakis, Carlos Vergara e Ana Maria Daou. E agradeço ainda, pelo apoio para a conclusão deste artigo, a Juva Batella, Adriana Nóbrega e Antônio Kuschnir Castro.

3 A disciplina foi oficialmente registrada na forma de "Tópicos especiais" e teve duração de 60 horas ao longo de um semestre letivo (2013-1). Todas as imagens inseridas nesse artigo foram produzidas durante o curso. O desenho inicial foi feito por mim num Ipad (App Adobe Ideas, caneta Bamboo) a partir de uma fotografia tirada em sala de aula. Aproveito para agradecer a todos os estudantes que colaboraram com a pesquisa ao longo do curso e que cederam seu tempo, suas imagens e seus textos para a pesquisa. 
da rede internacional Urban Sketchers, conhecidos em português como "desenhadores urbanos" (Kuschnir 2011). A representação do grupo foi fundada no Brasil naquele ano, com desenhadores de São Paulo e de várias outras capitais. No Rio de Janeiro, porém, os poucos "correspondentes" nunca chegaram a se organizar, nem a propor uma agenda de encontros públicos com ampla divulgação e frequência, como vem ocorrendo em outras cidades.

Em 2012 e 2013 o cenário continuou o mesmo. De repente, os "nativos" (os desenhadores urbanos) previstos no meu projeto simplesmente não existiam no Rio de Janeiro. Cheguei a procurar em outros universos, como os dos estudantes de artes, de arquitetura e de design. Algumas pessoas desses meios realmente gostam de desenhar e/ou frequentam aulas de desenho em cursos livres ou universitários. Mas a vida urbana raramente tem destaque nesse mundo - aparentemente mais voltado para o aperfeiçoamento da técnica, da ilustração e das artes. Como expliquei em Kuschnir (2011, 2012), eu precisava encontrar desenhadores interessados na experiência e na interlocução com as pessoas e a cidade em que viviam, trabalhavam, visitavam etc.

Foi diante de tal vazio que tive a ideia de criar o meu próprio grupo de "desenhadores urbanos". Quem sabe eu conseguiria convencer os alunos de Ciências Sociais do IFCS a se interessar pela ideia? Minha aventura era ao mesmo tempo investigativa e didática, e com um duplo desafio: (i) ensinar técnicas de desenho que pudessem ser utilizadas a curto prazo pelos alunos e (ii) fazê-los praticar esse conhecimento em pesquisas de campo na forma de pequenas etnografias urbanas que, por sua vez, me ajudariam a pensar antropologica e graficamente a cidade do Rio de Janeiro.

Para não criar suspense, digo desde já que, para mim, a experiência foi um sucesso, tanto do ponto de vista didático quanto investigativo. Também tive a sorte de receber resultados e avaliações muito positivas por parte de alunos, bolsistas e parceiros envolvidos.

A disciplina teve 26 alunos inscritos, incluindo três bolsistas do LAU que me ajudaram na realização e no registro de todas as atividades desenvolvidas ao longo do semestre, e mais dois alunos ouvintes. Foram 29 dias letivos (num total de aproximadamente sessenta horas didáticas), com vinte oficinas práticas mescladas com reflexões teóricas. Rebemos professores palestrantes convidados em sete aulas para debates e oficinas. Fizemos também visitas externas ao Centro Municipal de Arte Hélio Oiticica e ao ateliê do artista Carlos Vergara. ${ }^{4}$

Todas as atividades foram registradas através de 1044 fotografias e dez filmagens (transcritas posteriormente), além da digitalização de 415 trabalhos produzidos em aula. Cada aluno realizou também dois trabalhos de campo que geraram uma coleção de 25 composições de desenhos e textos sobre um tema comum (no entorno do IFCS) e quinze pesquisas (de cerca de dez a quinze páginas cada) ilustradas com desenhos etnográficos, feitas individualmente ou em duplas, em diferentes áreas da cidade do Rio de Janeiro. Esse material foi também objeto de pesquisa dos bolsistas do LAU, com resultados apresentados em dois eventos. ${ }^{5}$

4 Remeto aqui à experiência de Andrea Barbosa, coordenadora e professora de oficinas fotográficas com jovens da periferia de Guarulhos, que muito me inspirou nesse projeto (ver Barbosa 2012b).

5 Os bolsistas apresentaram seus trabalhos na Jornada de Iniciação Científica da UFRJ (Pedro Ferraz Gama: Contribuições do desenho para a pesquisa antropológica*; Carlos Henrique Alves de Sousa: A linguagem do desenho no ensino de antropologia; e Vinícius Azevedo: A linguagem da pichação: uma análise etnográfica da produção de grafismos na cidade) bem como no Seminário Imagem, Pesquisa e Antropologia (Visurb/ABA), na Unifesp (neste com a presença também de Maíra Mafra, como co-autora, a quem agradeço por se juntar à equipe 
Ao final de cada atividade os alunos foram também convidados a fazer uma avaliação por escrito e/ou com desenhos, o que resultou em 145 fichas, sempre protegidas pelo anonimato. Tivemos ainda vinte respondentes a um formulário de avaliação (também anônimo) ao final do curso, com perguntas elaboradas pelo bolsista Carlos Henrique Sousa (com a participação da equipe do LAU), cuja pesquisa tem como foco justamente a experiência didática realizada. ${ }^{6}$

O objetivo de todo esse esforço era, como dito inicialmente, ensinar alunos de graduação em Ciências Sociais a realizar uma pesquisa antropológica em que experimentassem desenhar como parte do processo de observação participante e em que seus desenhos feitos em campo fossem também tratados como material de análise e de apresentação dos resultados. Nesse sentido, tomamos a direção apontada por Bela Feldman-Bianco e Miriam L. Moreira Leite (1998) quando afirmam ser crucial tratar a dimensão imagética de uma pesquisa não como "documento da 'realidade objetiva' ou como mera ilustração de textos verbais", e sim como um material pleno de significados culturais produzidos a partir das interações entre "pesquisadores, pesquisados, produtos e contextos históricos” (p. 12). ${ }^{7}$

Ao estimular os alunos a realizar uma pequena etnografia urbana, parti da perspectiva teórica de que a pesquisa de cunho etnográfico é essencial para a formação em antropologia (Peirano 1992) e de que parte desse treinamento passa por se aprender a investigar nossa própria sociedade. Concordo, portanto, com Gilberto Velho (1978) quando afirma que nossa familiaridade com a cidade em que vivemos não a torna necessariamente conhecida. Como aponta o autor, muitas vezes navegamos na metrópole munidos de mapas cristalizados e repletos de estereótipos. A observação etnográfica detalhada e cuidadosa apresenta-se como um poderoso meio de reconhecer as "descontinuidades vigorosas entre o mundo do pesquisador e outros mundos" (p. 73) levando a uma maior compreensão da complexidade da vida urbana. Apoiei-me também na afirmação de Magnani (2002) de que o método etnográfico produz um conhecimento marcado pelo encontro pesquisador-pesquisado, onde a "explicação nativa" permite que o esquema teórico do pesquisador se torne "vivido". Nesse encontro, o método etnográfico produz um conhecimento "de perto e de dentro" sobre a cidade, capaz de "identificar, descrever e refletir" aspectos excluídos em outras abordagens disciplinares (p. 17).

Para sustentar a hipótese de que meus alunos poderiam aprender a desenhar em poucas semanas, baseei-me principalmente em Edwards (2001), Brookes (1996), Gregory (2003,

do LAU). *A apresentação de Pedro foi selecionada como a melhor de sua sessão, sendo premiada com a possibilidade de publicação na Revista do CFCH/UFRJ (ver Gama e Kuschnir, no prelo).

6 A avaliação final foi feita através de um formulário eletrônico. Seu objetivo era tanto ouvir os alunos sobre a experiência da disciplina como planejar seus futuros desdobramentos. As perguntas, respondidas de forma anônima e com espaço livre, foram: $\mathrm{O}$ que você esperava da disciplina quando se inscreveu?; Como era sua relação com o desenho antes de se inscrever na disciplina?; Você conhecia algum exemplo de utilização do desenho como ferramenta na antropologia?; A disciplina contribuiu para a sua prática como pesquisador?; Marque as três Oficinas que você mais gostou; Marque as três Oficinas que você MENOS gostou; Você acha que essa disciplina deveria ser oferecida como curso de Extensão?; Se sim, quais dias, horários e duração?; Gostaria de mencionar algo que não foi perguntado?; Idade; Sexo; Curso; Período atual.

7 É importante notar, porém, que quase sempre o conceito de "imagem" na bibliografia da área de antropologia visual está associado às produções fotográfica e filmica, como chama atenção Afonso (2004). Para um exemplo, ver Samain (2012). No entanto, é o desenho que há muito mais tempo vem solucionando o problema dos limites da linguagem verbal, como nos lembra Sennet (2009:111). 
2006) e Salavisa (2008), bem como em minha própria experiência como desenhadora e leitora de centenas de fontes sobre desenho nos últimos anos (Kuschnir 2011). A obra de Edwards é conhecida mundialmente e também serve de referência para as demais citadas. A autora propõe um conjunto de práticas que levam uma pessoa a desenhar, por observação, de forma "realística" e em poucos dias de treinamento. A proposta baseia-se na percepção de que desenhar é uma "habilidade global", assim como ler, dirigir ou andar de bicicleta. Uma vez aprendida, não se perde; necessita apenas de "prática, refino e técnica". Edwards argumenta que qualquer pessoa com capacidade de produzir uma caligrafia legível tem a destreza necessária para desenhar. Outro ponto central em sua teoria do aprendizado do desenho é que o foco não é ensinar uma habilidade manual, e sim uma habilidade visual:

Não preciso dizer mais nada sobre mãos aqui, mas sobre olhos não há como dizer o bastante. Aprender a desenhar é mais do que desenvolver a habilidade em si. Lendo este livro, você aprenderá a ver. (...) Desenhar não é difícil. O problema é ver, ou, de modo mais específico, passar a ver de uma forma específica. (p. 29-30)

Para Edwards, essa forma específica de ver está relacionada ao hemisfério direito do cérebro, responsável por nossa navegação "visual-espacial"; responsável por nossa capacidade de "perceber e de avaliar, de forma não-verbal, o relacionamento entre tamanhos, curvas, ângulos e formas" (p. 73). Para aprendermos a ver dessa forma, precisamos "desligar" nossas percepções da modalidade racional-verbal. Edwards demonstra tais princípios através de um exercício em que dois rostos e um vaso se confundem numa mesma imagem. Para desenhá-la é preciso deixar de se perceber um vaso ou um rosto (com seus marcadores cognitivos: boca, nariz, olhos, testa; ou base, bojo etc.), e passar a se perceber visualmente apenas linhas, proporções e espaços (p. 72-76).

Como afirmei acima, Brookes (1996), Gregory $(2003,2006)$ e Salavisa (2008) tratam do aprendizado do desenho com afinidade aos princípios da obra de Edwards (2001), originalmente publicada em 1979. São autores voltados para o público em geral - público que tanto se assemelha ao meu próprio universo de alunos de Ciências Sociais, quase todos sem experiência de desenho na idade adulta. Para uma debate acerca do ensino da arte na escola, no entanto, seria importante avançar numa análise das perspectivas modernistas e de suas influências marcantes (John Dewey, por exemplo), como no fascinante Ensino da arte: memória e história, organizado por Ana Mae Barbosa (2008).

Não está ao meu alcance, no momento, fazer as pontes entre esses dois universos de reflexão sobre desenho, embora existam afinidades e diálogos entre eles. Ambos me ajudaram a produzir as propostas e os exercícios que tornaram possível ensinar alunos de antropologia a utilizar o desenho em suas pesquisas etnográficas. Posso dizer que, nos aspectos práticos e técnicos, a obra de Edwards foi crucial, especialmente suas três etapas iniciais: bordas, espaços e relacionamentos (p.19). Afasto-me, no entanto, de sua perspectiva quando o projeto se torna mais voltado para uma busca do aperfeiçoamento artístico (etapas "Luzes e sombras", e "Gestalt").

Sinto-me claramente mais alinhada com o caminho proposto por Barbosa (2008) e exemplificado de forma vívida num de seus capítulos sobre a Escolinha de Arte Cândido Portinari. Seu autor, Vicente V. M. Carvalho, mostra que ali o objetivo era forjar um espaço de criação e experimentação, sem foco na formação de "artistas" ou em obras esteticamente adequadas para sua época. Creio que Gregory e Salavisa, já citados, seguem nessa mesma direção, assim como muitos dos membros da rede Urban Sketchers, que valorizam não o virtuosismo técnico, mas a experiência de desenhar - ou seja, o processo é mais importante do que seus resultados. Nesse 
caminho também é mais importante aprender uma nova forma de olhar o mundo do que "desenhar bem", conforme procurei explorar em Kuschnir (2011 e 2012).

Não é difícil perceber o quanto esse objetivo se aproxima daquele que poderíamos almejar num projeto de ensino de prática etnográfica. Para Roberto Cardoso de Oliveira (2000), o olhar é parte essencial da prática do antropólogo, assim como as habilidades de escutar e escrever. Não se trata de um olhar neutro, mas de um olhar que se vai construindo no processo de formação do pesquisador.

Talvez a primeira experiência do pesquisador de campo - ou no campo - esteja na domesticação teórica de seu olhar. Isto porque, a partir do momento em que nos sentimos preparados para a investigação empírica, o objeto, para o qual dirigimos o nosso olhar, já foi previamente alterado pelo próprio modo de visualizá-lo. (Oliveira 2000: 19)

Para o autor, objetos, pessoas e contextos são "apreendidos pelo esquema conceitual da disciplina formadora de nossa maneira de ver a realidade" - é da antropologia que vem o "prisma por meio do qual a realidade observada sofre um processo de refração" (p. 18-19). Sendo assim, exemplifica Oliveira, um etnógrafo bem preparado não vê apenas o interior de uma maloca; ele observa fogos, cozinhas, grupos domésticos, seres sociais. Ele vê esse universo através da literatura etnológica atual e histórica. ${ }^{8}$

Meu objetivo nessa proposta de ensino foi então mostrar aos alunos que antropologia e desenho são modos de ver e também modos de conhecer o mundo. Colocar esses dois universos em diálogo permite, na minha hipótese de pesquisa, um enriquecimento mútuo - isto é, desenhar contribui positivamente para a pesquisa antropológica, e vice-versa: pesquisar antropologicamente contribui para desenharmos o mundo à nossa volta.

Como eu tinha um grupo de estudantes já familiarizados com etnografia, minha tarefa inicial foi aproximá-los da prática do desenho. Posso dizer que o que era apenas a minha pesquisa se tornou um projeto de investigação (e diversão!) coletiva. Seria impossível narrar aqui tudo o que desenvolvemos nas sessenta horas de curso e nas muitas horas gastas nos trabalhos de campo. Escolhi, portanto, apresentar apenas algumas aulas-chave como exemplos etnográficos da investigação.

Dividi a disciplina em quatro módulos: "Explorando o etnógrafo", "Explorando a cidade", "Etnografia e desenho" e "Pesquisa e desenvolvimento". A sequência tinha como propósito estabelecer as pontes entre pesquisa e desenho, pensando o ato de desenhar como tornar visivel, narrar, compreender, produzir, apropriar-se de e conhecer. Cheguei a essa definição através de vários autores, como mostro em Kuschnir (2011 e 2012). Aproximo-me aqui também de Massironi (2010), que chama a atenção para os infinitos objetivos dos desenhos. Anotação gráfica que serve para "descrever ou explicar um mundo de fenômenos", o desenho é um ...

... instrumento tão simples mas, ao mesmo tempo, tão intrinsecamente elástico que permite a narração, dos mais diversos modos, da complexidade, e cada vez mais dilatável para cobrir a possibilidade expressiva. (Massironi 2010:17)

8 Para um outro descentramento dos modos de ver, remeto ao trabalho de Turner (2005) sobre as cores no ritual Ndembu. 
No quadro a seguir vemos uma síntese dos quatro módulos e vinte oficinas propostas ao longo da pesquisa (lembrando que cerca de $35 \%$ das aulas foram dedicadas à apresentações teóricas e debates, não incluídas no quadro abaixo):

\begin{tabular}{|l|l|}
\hline Módulo I & Explorando o etnógrafo \\
\hline Oficina 1 & Formas e contornos \\
\hline Oficina 2 & Encontrando linhas \\
\hline Oficina 3 & Elementos básicos da forma \\
\hline Oficina 4 & Caderno feito à mão (com Elisa Kuschnir e Celina Kuschnir) \\
\hline Oficina 5 & Tipografia \\
\hline Oficina 6 & Espaços negativos (em monotipia) \\
\hline Módulo II & Explorando a cidade \\
\hline Oficina 7 & Desenhando com a cidade (com ESDI) \\
\hline Oficina 8 & Mapas, mapeamento e representação gráfica \\
\hline Oficina 9 & A criança no centro da cidade (com CECIP) \\
\hline Oficina 10 & Um mapa afetivo (com CECIP) \\
\hline Oficina 11 & Carimbos sobre a cidade \\
\hline Módulo III & Etnografia e desenho \\
\hline Oficina 12 & Pintura corporal e grafismo indígena (com Els Lagrou) \\
\hline Oficina 13 & Desenho no Centro Munic. de Arte Helio Oiticica \\
\hline Oficina14 & Fotografia etnográfica e intervenções gráficas (com VISURB) \\
\hline Oficina 15 & Desenho de observação I \\
\hline Oficina 16 & Desenho de observação II \\
\hline Módulo IV & Pesquisa e desenvolvimento \\
\hline Ofícina 17 & Pesquisa coletiva - Gatos no Centro da cidade \\
\hline Oficina 18 & Visita ao Atelier Carlos Vergara \\
\hline Oficina 19 & Arte das manifestações e produção de cartazes \\
\hline Ofícina 20 & Ilustração: uma conversa de texto e imagem \\
\hline Finalização & Apresentação dos trabalhos finais \\
\hline
\end{tabular}

Meu objetivo no Módulo 1, "Explorando o etnógrafo”, era apresentar aos alunos esse conceito de desenho através de oficinas práticas. Além disso, como diz o título, iniciar um processo de transformação desses etnógrafos/pesquisadores em etnógrafos/ desenhadores. Ou seja, era preciso oferecer instrumentos para que todos se apropriassem da ideia de que podiam desenhar.

O exercício número 1 do curso foi criado a partir de experiências com meus filhos Antônio e Alice, na época com 12 e 7 anos, respectivamente. Como muitas crianças nessa faixa etária, eles já têm resistências e críticas quanto aos resultados de seus desenhos (Brookes 2009). Por conviverem com uma mãe que desenha com frequência, essa voz autocrítica se revelou quase tão potente quanto a dos meus alunos adultos (ou pós-adolescentes, em alguns casos).

Esse exercício inicial, portanto, precisa ser extremamente simples e ao mesmo tempo capaz de produzir resultados complexos. As etapas devem ser cumpridas coletivamente, para que o resultado visual de cada uma não interfira no processo seguinte. O ideal é que toda a turma, enquanto troca ideias sobre cada etapa, vá percorrendo os estágios mais ou menos ao mesmo 
tempo. $\mathrm{O}$ exercício segue a sequência abaixo enumerada:

1 - Separe o material necessário: jornais, revistas, canetas hidrocor pretas (grossas e finas), tesouras (de diferentes tamanhos), cola, papel tamanho A4 colorido, papel craft grande (opcional).

2 - Selecione uma fotografia publicada em jornal ou revista em que apareça uma pessoa em corpo inteiro (em qualquer posição, desde que você possa perceber uma figura dos pés à cabeça).

3 - Recorte um retângulo em torno dessa imagem, de modo a obter a fotografia completa ou a imagem da pessoa no contexto em que foi publicada.

4 - Pinte cuidadosamente toda a figura humana na cor preta com as canetas hidrocor (finas ou grossas, dependendo do tamanho da figura e de suas partes).
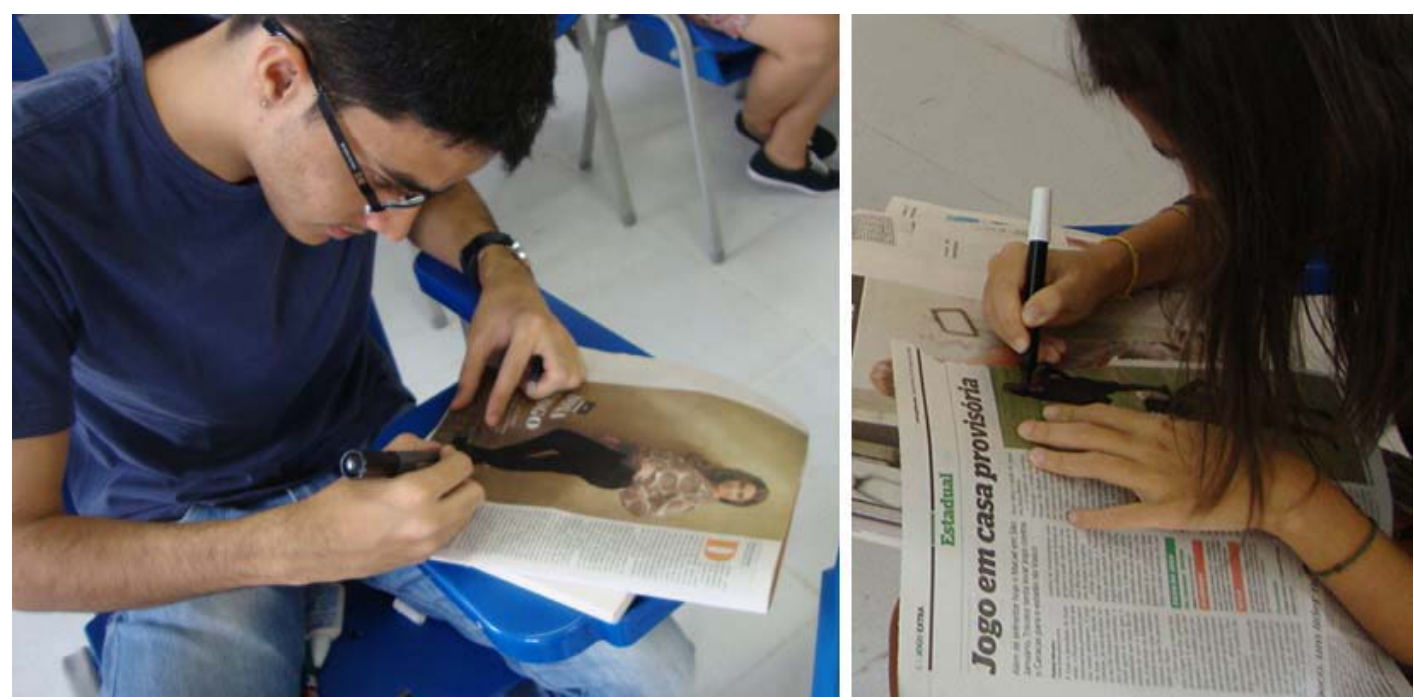

5 - Recorte delicadamente a figura pintada de preto, tomando cuidado para que a tesoura passe por todos os contornos, sem os desfigurar e mantendo a moldura inteira, exceto pelo corte de entrada da tesoura.

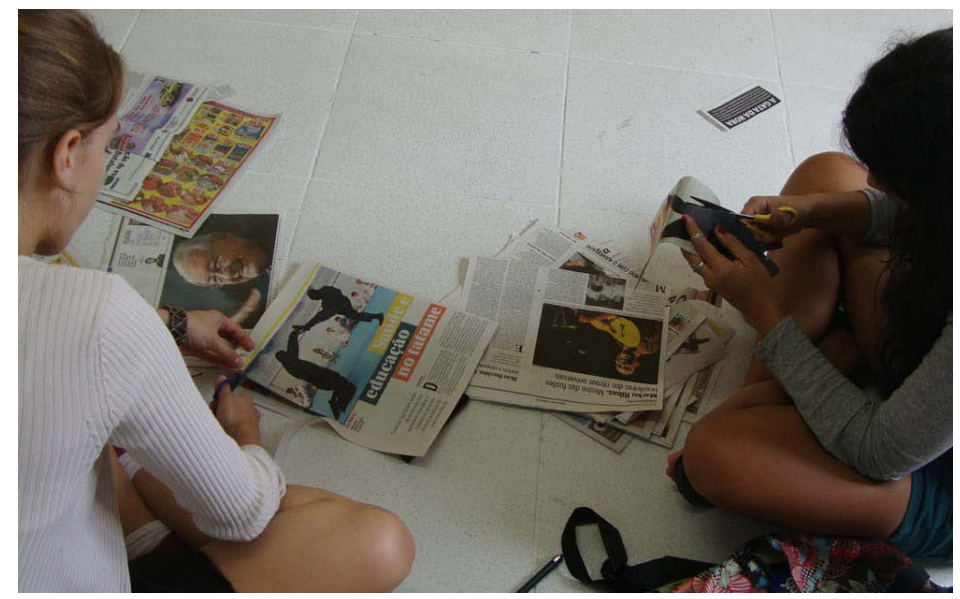


6 - Coloque sobre o papel craft grande a figura humana recortada, junto com as outras que a turma recortou. Observe as peças individualmente e em conjunto.

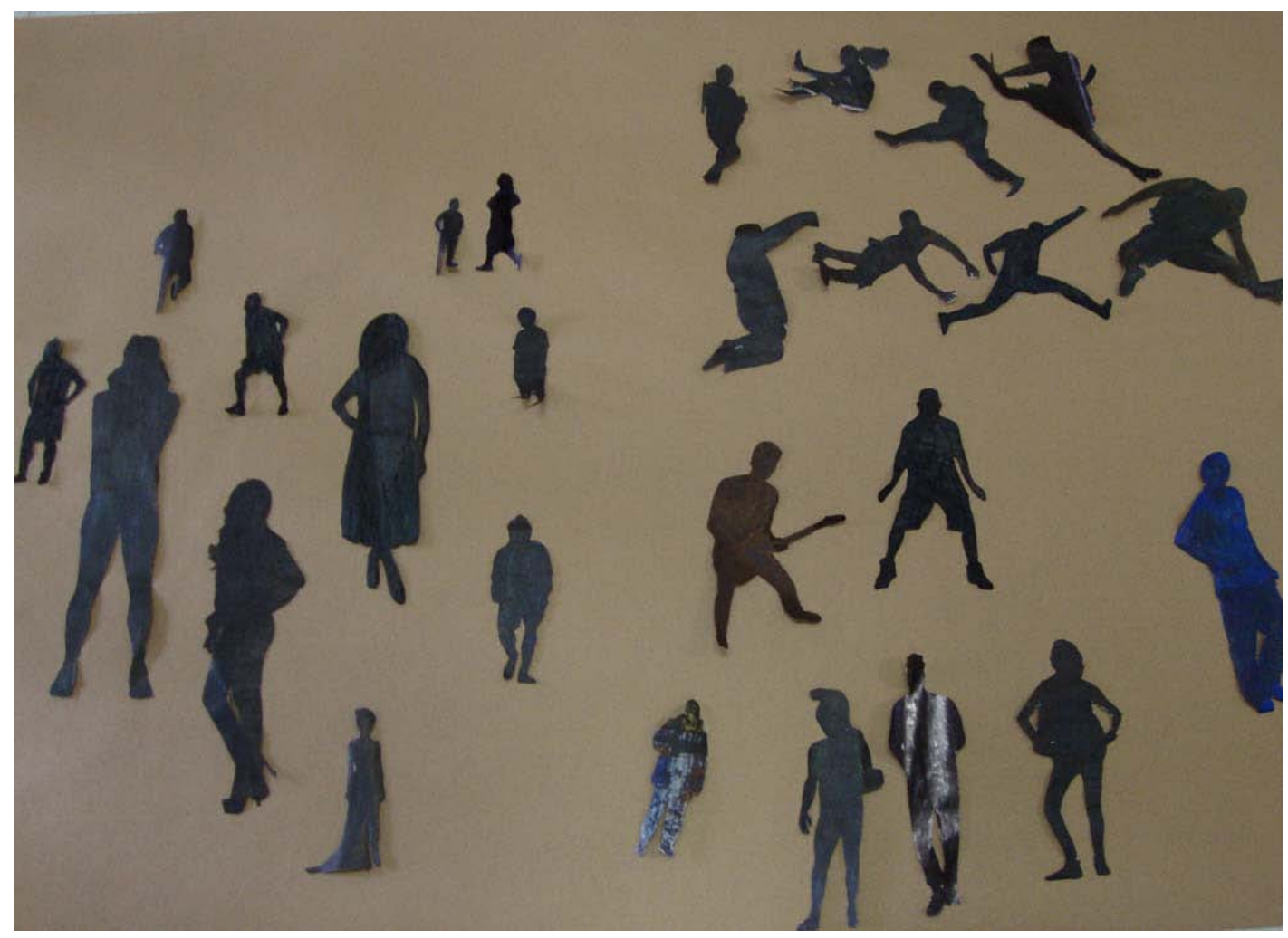

7 - Coloque a moldura recortada sobre um papel tamanho A4 colorido, junto com as demais produzidas pela turma. Observe.

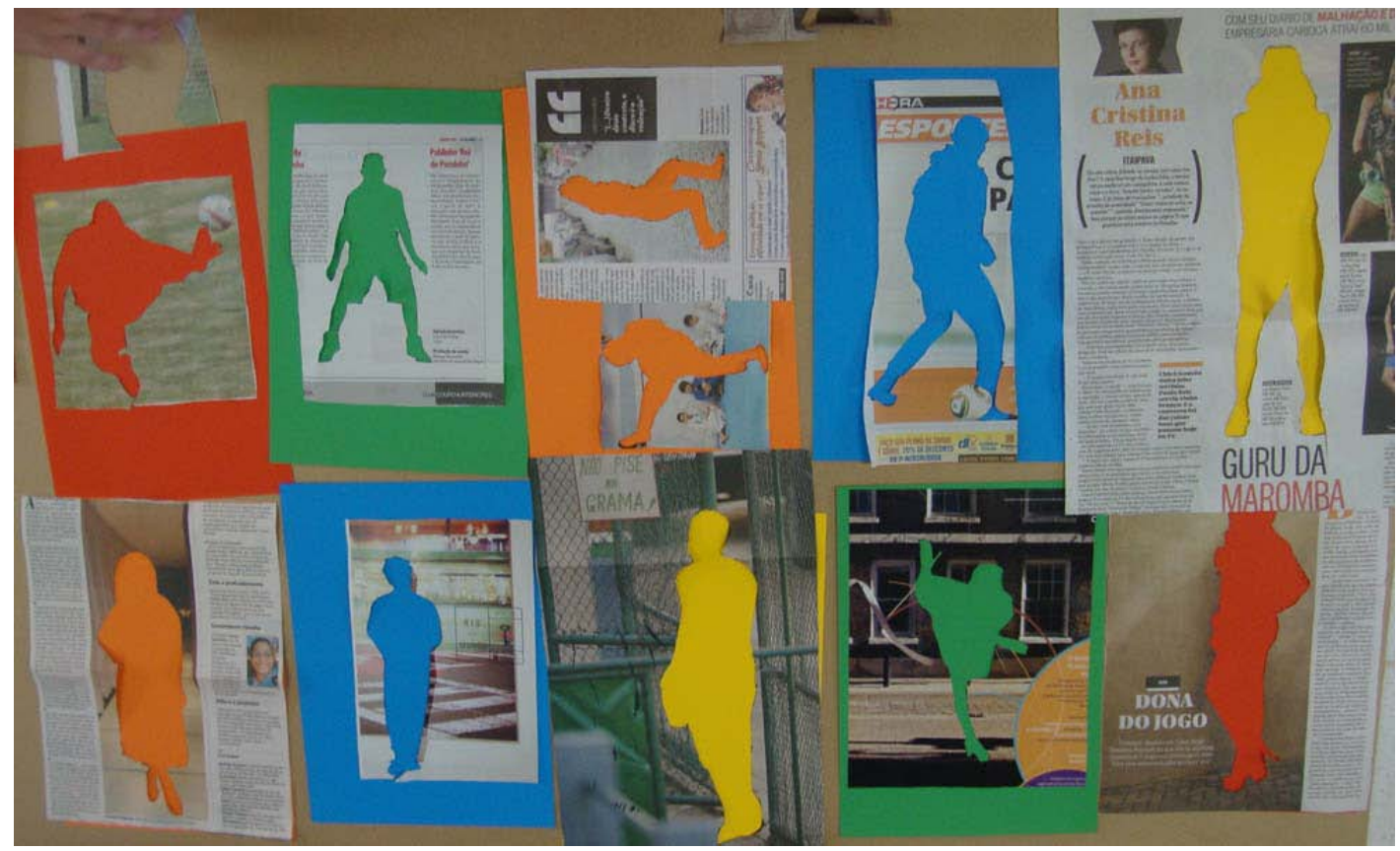

8 - Utilize os dois recortes para produzir desenhos, seja traçando o contorno externo (da figura pintada de preto), seja traçando o contorno interno (da moldura). 

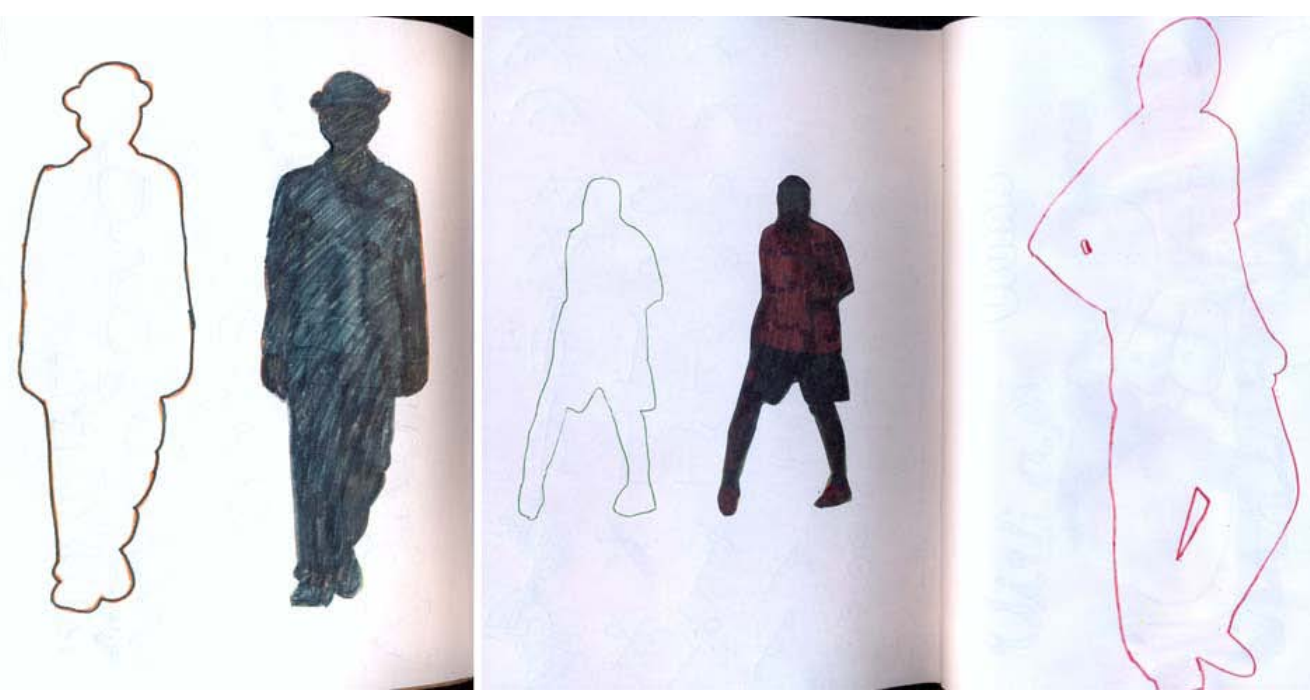

9 - Reflita sobre os significados ou re-significados produzidos pelos novos desenhos e suas combinações.

10 - Como tarefa de casa, explore o mesmo processo também com imagens de objetos. Explore redesenhar com os recortes produzidos em sala.

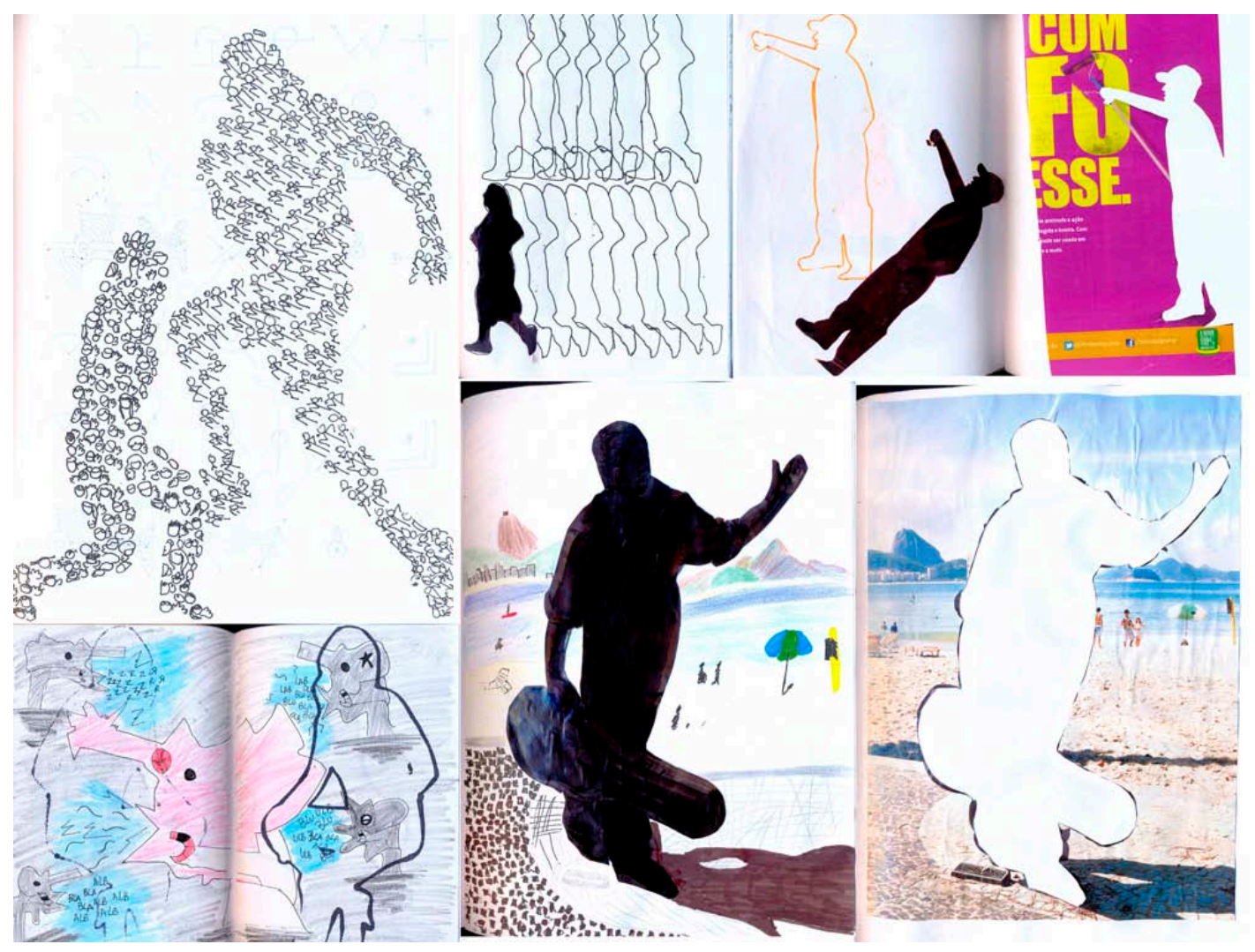

Ao longo da atividade, acompanhei o trabalho dos alunos para tirar dúvidas e observar. $\mathrm{Na}$ parte técnica, a única dificuldade foi recortar figuras muito pequenas ou com detalhes sinuosos (como dedos separados). Mesmo nesses poucos casos, todos cumpriram as etapas, muitos mais de uma vez. Foi consenso que o exercício era "fácil" e "divertido". Os alunos também comentaram bastante o fato de estarem "pela primeira vez na vida" fazendo uma oficina prática na facul- 
dade de Ciências Sociais. Sentar no chão e mexer em papéis, canetas e tesouras são atividades que não realizavam numa sala de aulas desde que eram crianças.

De modo a que seus objetivos fossem concluídos pelos próprios alunos, e não por mim, professora, sugeri, diante das imagens produzidas pelos recortes, que conversássemos sobre a atividade. Uma aluna apontou para o fato de que "pintar" as fotografias de preto fez com que passássemos a vê-las em apenas em duas dimensões. Outra comentou que isso facilitava nossa percepção dos contornos e das formas humanas, aproximando-os da linguagem do desenho.

Sugeri que colocássemos as formas recortadas juntas sobre um papel, buscando algum tipo de classificação, como cientistas sociais costumam fazer. Houve uma separação entre imagens que pareciam estáticas e imagens em movimento; e também uma classificação por tamanho. Experimentamos agrupá-las de modo a perceber suas afinidades e também como a sua disposição no papel alterava nossa percepção da relação entre elas, assim como a sensação de profundidade que produziam (ver imagem acima).

Todos concordaram com a ideia de que reproduzíamos ali conjuntos de imagens familiares, mentalmente associadas a outras imagens por nós conhecidas (cf. Barthes 1990). Isto é, reconhecemos nossa própria "alfabetização" visual, no contexto das tecnologias em que vivemos. Por exemplo, ao separar formas humanas maiores e menores, não imaginamos a existência de pessoas grandes e pequenas, mas sim pessoas mais ou menos distantes de quem as fotografou, familiarizados que estamos com as regras da representação renascentista da perspectiva.

Da mesma forma, ao separar imagens que nos pareciam menos estáticas do que outras, também percebemos o quanto essa imaginação se deve aos registros fotográfico e fílmico, que nos familiarizaram com a possibilidade de "congelar" o movimento em posições antes inimagináveis. Um marco histórico dessa transformação se deu a partir da série de fotografias sobre movimento feitas por Eadweard Muybridge (entre elas a famosa "The Horse in Motion"). O fotógrafo não apenas demonstrou que os cavalos não voam quando correm, como revolucionou a maneira a partir da qual percebemos visualmente o movimento de animais e pessoas, influenciando também outras artes visuais. ${ }^{9}$

Conversamos ainda sobre como aquelas imagens seriam vistas, classificadas e dispostas sobre o papel se fôssemos indivíduos originários de outras sociedades/ culturas, um tema que pudemos experimentar também de forma prática e lúdica na oficina ministrada pela professora Els Lagrou sobre grafismo corporal indígena, em especial o dos Kaxinawa, sobre a qual falarei mais adiante.

Através das figuras recortadas, portanto, pudemos propor uma discussão fundamental durante todo o curso: o que estamos aptos a ver, ou seja, quais imagens estão dadas antes mesmo de abrirmos os olhos (Kuschnir 2011 e 2012). Ficou claro que nossa prenoção de "figura humana desenhada" não correspondia às muitas formas que tínhamos diante dos olhos, conforme sintetizou um aluno em sua ficha de avaliação daquela aula. Transcrevo a seguir o texto principal da ficha:

Achei as atividades propostas muito interessantes e didáticas, no sentido de que pude aprender a olhar em duas dimensões figuras que seriam em 3D. Ex.: "a forma humana". Pude perceber que a forma humana pode

9 Disponível em http://en.wikipedia.org/wiki/Eadweard_Muybridge. 
ser reconhecida em diversas posições e em diferentes tamanhos. Aprendi que a forma humana pode ser diferente de * [ver imagem acima], que pode ser até um borrão ou ponto. Assim, pude compreender que isso não só vale para retratar ou se referir ao "homem" mas aos objetos, lugares e ideias. PS: Noção de movimento $\mathrm{x}$ estático.

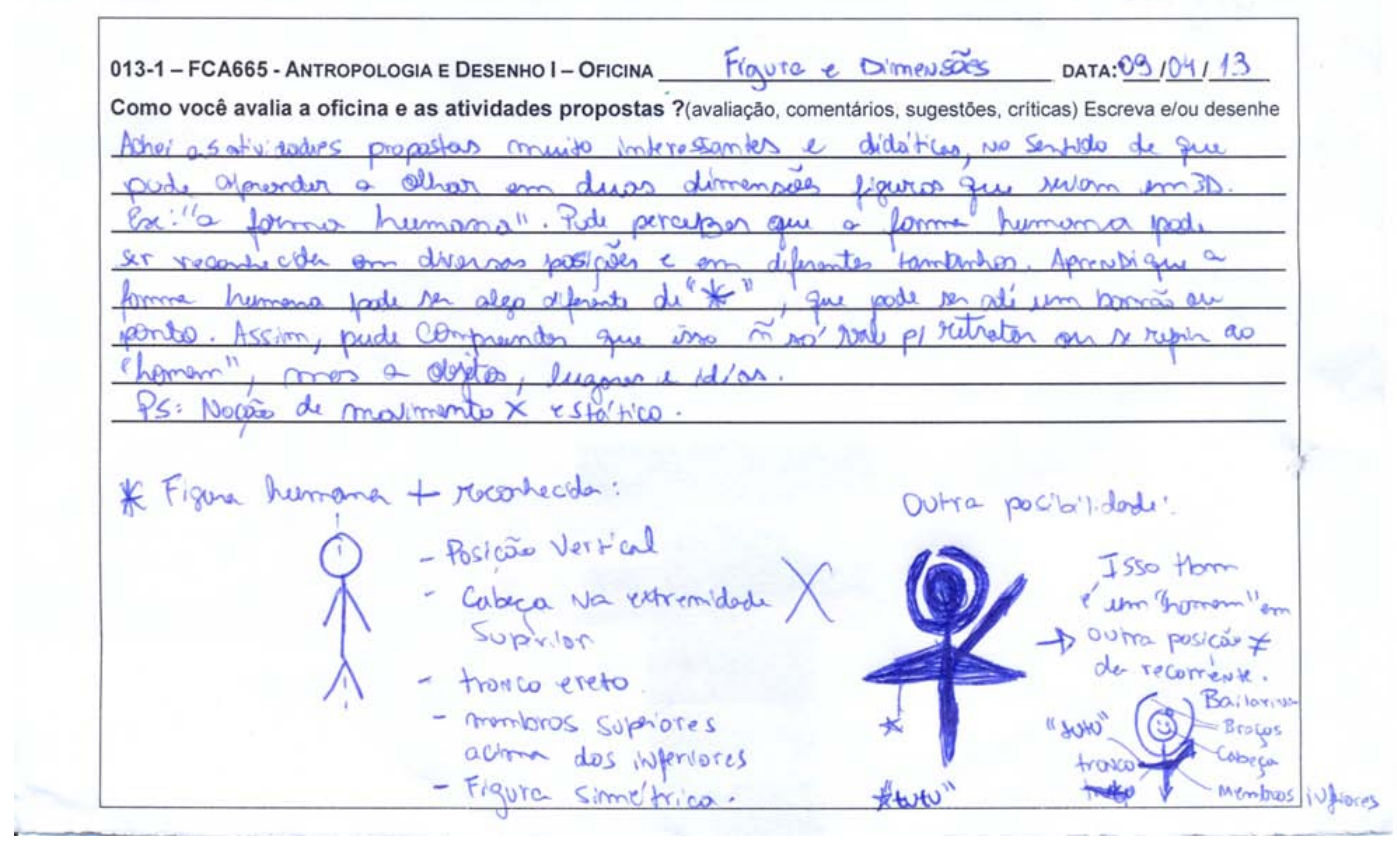

Por meio de desenhos o aluno complementa sua explicação. Do lado esquerdo ele traça uma "Figura humana mais reconhecida" com as anotações "posição vertical, cabeça na extremidade superior, tronco ereto, membros superiores acima dos inferiores, figura simétrica”. Do lado direito, uma "Outra possibilidade": "Isso também é um 'homem' em outra posição diferente da recorrente".

Pela troca coletiva de ideias e pelas fichas de avaliação, concluo que o grupo chegou com facilidade a um dos objetivos centrais do exercício: perceber a analogia entre método antropológico e método de desenho por observação. É necessário afastar, em ambos, as prenoções, dadas cultural e historicamente, para construir um conhecimento novo. Seja por meio de imagens ou textos, essa é uma busca que se alimenta e se enriquece a partir do olhar, da escuta e do diálogo com seus interlocutores, sem os definir antecipadamente com base em percepções etnocêntricas e/ou visualmente estereotipadas.

Pudemos também nos aproximar do problema de como o contexto afeta a maneira de significarmos uma informação. Para ilustrar a ideia, mostrei aos alunos a imagem abaixo, reproduzida em Reichenstein (2013). 

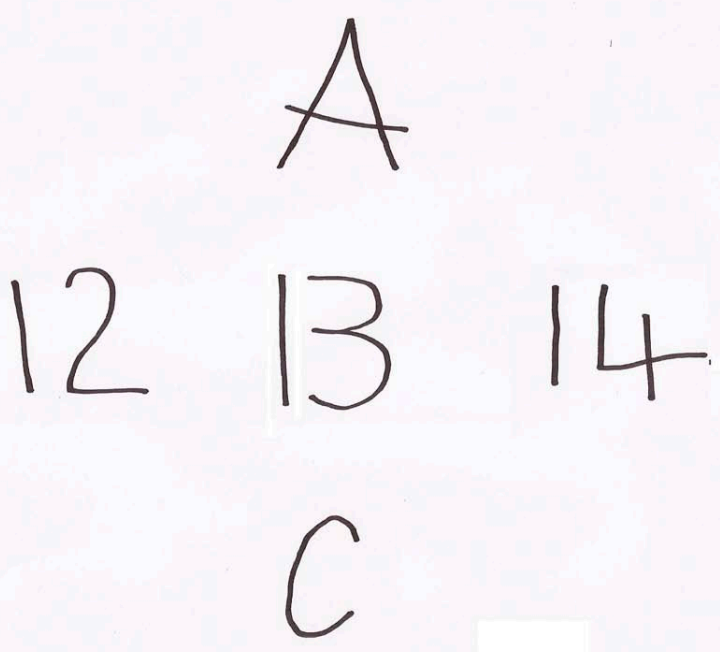

O que vemos na parte central dessa figura? $\mathrm{O}$ número 13 ou a letra $\mathrm{B}$ ? A representação gráfica é a mesma, mas seu significado muda dependendo da forma como "lemos" a imagem. $\mathrm{Na}$ vertical, de cima para baixo, nossa expectativa é "ver" uma letra; na horizontal, da esquerda para a direita, esperamos "ver" um número. Em ambas, na verdade, o significado 13 ou B é determinado pela forma, pelo ponto de vista e pelo contexto. Ou seja, o resultado é afetado pelo posicionamento do observador (na posição superior ou na lateral esquerda) e pelo significado dos demais elementos que compõem a cena observada (letras ou números). É da combinação desses três fatores (forma, ponto de vista e contexto) que surge o sentido da imagem vista.

Meus alunos eram como praticamente todos os estudantes de Ciências Sociais, que hoje já entram na universidade sabendo que, para se tornarem pesquisadores, precisam "relativizar" sua percepção de mundo. Podemos também dizer que faz parte da sua base disciplinar (em antropologia) ter consciência de que o contexto afeta o significado - no sentido tanto da formação cultural-étnica-e-histórica do pesquisador quanto de considerar as condições em que se dá a pesquisa, isto é, as mediações que possibilitaram o encontro entre pesquisador e universo pesquisado. $\mathrm{Na}$ prática, porém, minha experiência indica que todos nós (professores e alunos) temos dificuldade de transformar esse conhecimento (abstrato, i.e., aprendido através de aulas e leituras) em experiências de fato vividas e percebidas.

Esse era justamente um dos objetivos do nosso primeiro exercício: observar como operam tais deslocamentos de significado em relação a pontos de vista e contextos. Essa é uma operação (conceitual $e$ prático-metodológica) importante tanto para a antropologia como para o universo da representação gráfica e do desenho de observação. Colocar esses mundos em diálogo pode contribuir didaticamente para uma melhor formação em ambos. Como escreveram alguns alunos, misturando sem problemas as duas áreas de conhecimento: "A experiência trouxe questões do olhar antropológico sobre as formas"; instigou "a educar o olhar" e ensinou "a realizar pesquisas sobre formas de expressar ideias não só através das palavras”.

Ao analisarmos as formas cheias e vazias criadas em sala de aula, pudemos imaginar inúmeros deslocamentos e significados que se alteravam conforme interferências nas imagens. $\mathrm{Na}$ imagem com experiências feitas em casa pelos alunos (acima), vemos alguns exemplos do que 
mais tarde se tornou um procedimento bastante explorado por todos.

É importante lembrar também que um dos objetivos dos exercícios do curso era simplesmente proporcionar oportunidades para que os alunos praticassem o ato de desenhar. Logo de início muitos expressaram seu receio de fazer a disciplina, dizendo: "Professora, eu não sei desenhar". Uma aluna chegou a me dizer que iria trancar a matéria por "falta de talento", medo de não "acertar" ou de não conseguir "fazer bonito". Felizmente, ela não só não desistiu como acabou fazendo um excelente trabalho, pois nenhum desses adjetivos é prioritário para o tipo de desenho que buscamos.

O segredo para fazer com que os alunos praticassem o desenho na fase inicial da disciplina foi oferecer diversos suportes para o ato de traçar, ao invés de uma folha de papel em branco. Assim fizemos no primeiro exercício, onde formas cheias e vazadas serviram de apoio para o traçado de contornos. Do mesmo modo, no segundo exercício do curso, adaptei uma ideia proposta por Sonheim (2010) de usar imagens de calçadas quebradas como base para um desenho, adequando ligeiramente seus objetivos e forma de realização. A sequência proposta para os alunos foi a seguinte:

1 - Separe o material necessário: uma fotografia tamanho A4 de uma calçada de cimento quebrada (cf. exemplos abaixo), uma folha tamanho A4 de papel vegetal, 1 prendedor de papel pequeno (tipo "binder clip"), lápis grafite, lápis de cor, papel tamanho A4 branco, papel craft grande (opcional). (A fim de fornecer o material para a turma toda, fizemos 6 cópias de 5 fotografias diferentes. Para este exercício é importante ter variações na imagem de base, mas também é muito importante que a mesma imagem seja trabalhada por diferentes alunos.) calçada.

2 - Reserve de 3 a 5 minutos para olhar com calma as linhas formadas pelas rachaduras na
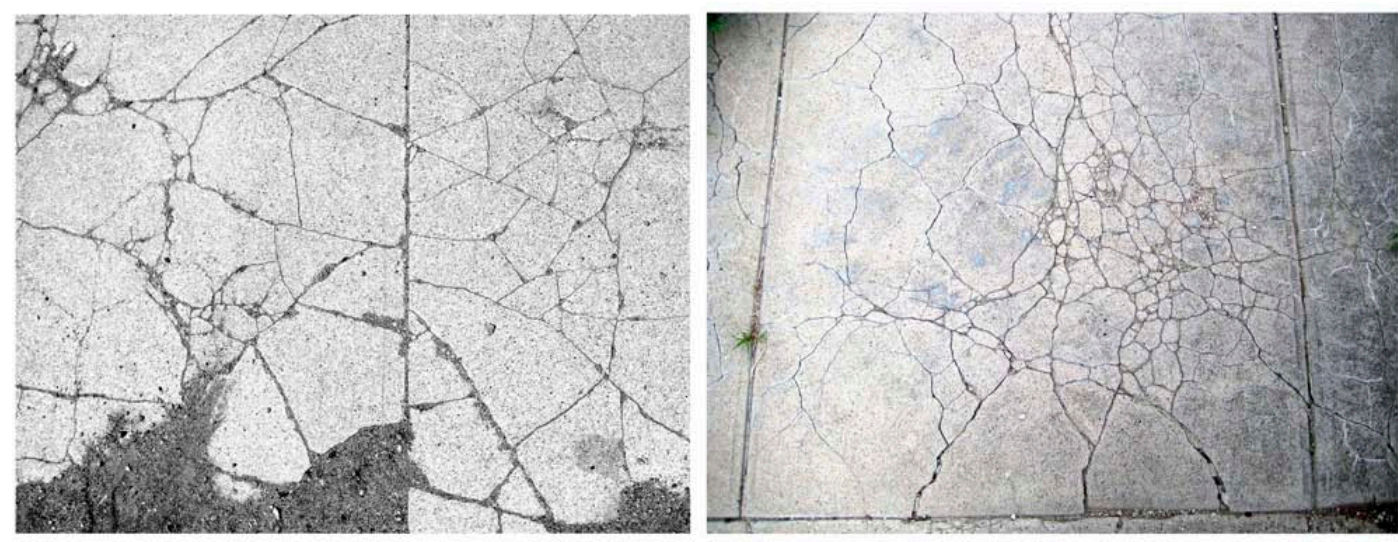

3 - Ponha um papel vegetal sobre a fotografia, prendendo-o com um clipe.

4 - Olhe atentamente as linhas disponíveis. Procure ver formas e significados nas relações entre elas. 


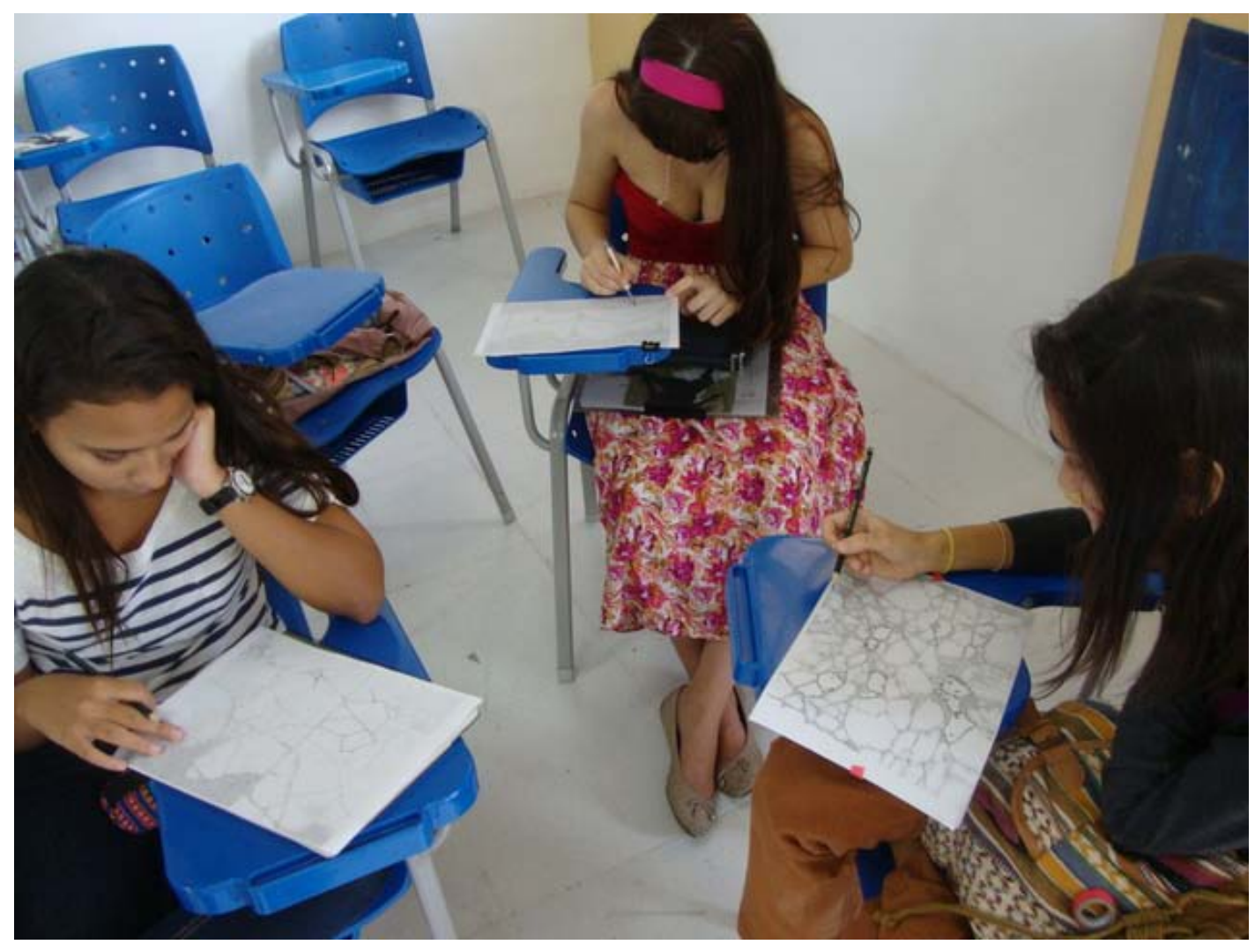

5 - Com um lápis, trace um desenho no papel vegetal utilizando apenas as linhas e formas já existentes na imagem fotográfica que está debaixo do papel vegetal.

6 - Utilize lápis de cor ou canetas para complementar o desenho realizado (opcional).

7 - Separe o papel vegetal da fotografia e coloque o desenho resultante sobre um papel branco.

8 - Disponha o desenho junto com outros feitos a partir da mesma fotografia para compará-los. (Abaixo podemos ver três desenhos feitos a partir da mesma fotografia - a que está à direita no item 1 deste exercício.)
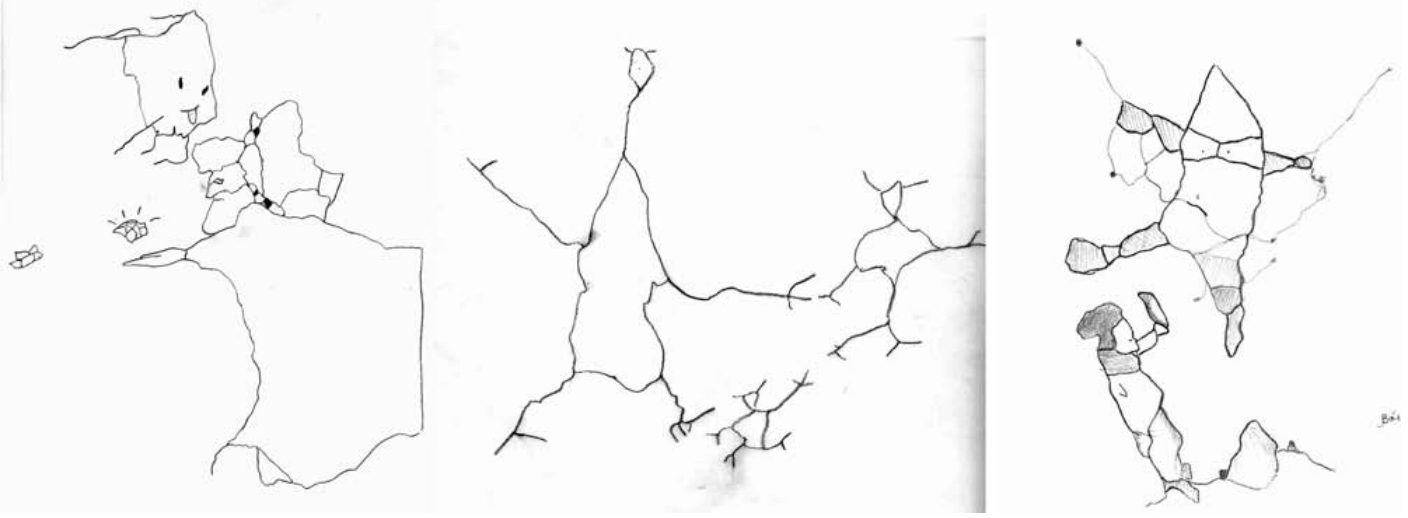

A atividade transcorreu de forma tranquila e silenciosa. Há uma concentração especial nesse tipo de aula. Os alunos se entregam à imagem, olhando-a com atenção e realizando a tarefa proposta. Foi consensual a ideia de que descobrir desenhos dentro de um emaranhado de 
linhas constitui um processo prazeroso, embora um pouco mais "difícil" (no sentido de exigir mais concentração) do que o do exercício anterior.

Depois que todos terminaram seus desenhos, colocamos as imagens lado a lado para analisá-las, conversando sobre o processo e seus resultados. Cada estudante falou brevemente sobre a sua produção e a dos colegas. Nessa primeira experiência com o exercício sugeri que procurassem nas imagens figuras de pessoas, animais ou criaturas fantásticas, seguindo a sugestão de Sonheim. (Na segunda vez que realizei a atividade, com outra turma, em 2014, deixei o tema livre - solução que me pareceu ter mais rendimento.)

O que se conseguiu com o segundo exercício foi:

1 - Oferecer um suporte que desse segurança para que alunos iniciantes desenhassem.

2 - Oferecer uma atividade de desenho lúdica, dificilmente associável a critérios de "certo $\mathrm{x}$ errado" ou "bonito x feio", uma vez que os traçados já estavam dados. Como apontou uma aluna, esse caráter de brincadeira favoreceu a "interação entre a turma" e foi um estímulo à criatividade e à imaginação.

3 - Oferecer a oportunidade de o aluno construir imagens que fujam das suas prenoções (padrões estereotipados), uma vez que as linhas de base não seguem qualquer modelo. (Vemos nos exemplos acima que o corpo humano foi representado com recursos gráficos muito distintos, permanecendo, no entanto, inteligível.)

4 - Demonstrar que uma mesma imagem pode ser vista de diferentes formas por diferentes indivíduos - daí a necessidade de se oferecerem fotos repetidas para diferentes alunos. (Ao fazer isso, demonstramos também a importância da análise comparativa, procedimento que todo cientista social precisa aprender a exercitar.)

5 - Apresentar uma nova forma de ver um elemento da vida urbana (calçadas), dando-se início ao processo de renovar nosso olhar sobre elementos que nos são aparentemente familiares na cidade em que vivemos (cf. Velho op. cit.).

Muitos desses resultados estavam na lista de metas que tracei para o exercício. Outros, no entanto, como apontei no item dois (acima), se revelaram surpreendentes. A animada participação dos alunos em comentários orais ou por escrito contribuiu muito para que todas essas etapas ganhassem vida. Numa ficha de avaliação da oficina, um deles escreveu uma ótima síntese dos resultados apontados acima nos pontos cinco e um:

Fizemos uma desconstrução do olhar sobre as imagens cotidianas, tirando a imagem de seu contexto e colocando em outro; e também aumentando a intimidade da mão com a imagem, a forma e o papel.

Outro resumiu perfeitamente o ponto três com suas próprias palavras:

Percebi que não preciso de linhas tão rígidas ou "corretas", que é possível me expressar sem necessidade de uma imagem perfeita. Passo importante para quebrar o paradigma do belo. 
Não tenho espaço neste artigo para continuar descrevendo e analisando detalhadamente todas as vinte oficinas realizadas, além dos longos trabalhos finais apresentados. ${ }^{10}$ Mas apresento a seguir um resumo do que fizemos após esses exercícios iniciais e de modo a oferecer uma visão geral do curso.

Ainda no Módulo 1 - "Explorando o etnógrafo" - produzimos mais quatro oficinas, e o objetivo era os alunos se apropriarem do ato de desenhar, nos moldes já apresentados acima. Fizemos exercícios com "elementos básicos da forma" (Brookes 2009), "espaços negativos" (Edwards 2001), tipografia (a partir do trabalho de Saul Steinberg) e monotipia (impressão com álcool). Tivemos também a participação de Elisa Kuschnir e Celina Kuschnir, ambas designers (e minhas sobrinhas), como professoras convidadas para ministrar a aula "Caderno feito à mão".

A atividade trouxe um ganho enorme para a turma, e não só pelo aprendizado da técnica de construção de um objeto. A oficina acabou tornando-se um rito de passagem para os alunos, acelerando sua transformação: de alunos-pesquisadores em alunos-pesquisadores-que-desenham, um objetivo fundamental de toda essa experiência didática. Durante o processo, discutimos o papel do caderno de campo na pesquisa, comparando seus usos por designers, viajantes, artistas e cientistas sociais. Vimos diferentes cadernos feitos à mão, bem como exemplos de seus rendimentos quando utilizados por pesquisadores que desenham - a exemplo de Taussig (2011), que fez uma importante reflexão sobre o tema. A partir desse dia, o caderno produzido por cada um tornou-se o local de registro ou incorporação dos desenhos feitos em aula e durante as pesquisas de campo, passando a fazer parte do material indispensável do curso. ${ }^{11}$

No Módulo 2 - "Explorando a cidade" - as atividades desenvolvidas foram voltadas para o debate com a antropologia urbana e para o mapeamento da cidade, temas que não vou apresentar com detalhes, por estarem menos identificados com os objetivos deste artigo. Tivemos um espaço de experimentação e discussões muito rico, que se tornou possível devido à participação de pesquisadores convidados, tais como Zoy Anastassakis (hoje coordenadora do Laboratório de Design e Antropologia, LaDA/Uerj) e a equipe do Cecip (Centro de Criação de Imagem Popular), representada por Moana Van de Beuque, Claudius Ceccon e Nazaré Salutto. ${ }^{12}$ Fizemos diversos exercícios de representação gráfica, desenhos de mapas e percursos de orientação (cf. Niemeyer 1998), bem como uma oficina de carimbos - tudo isso tendo como tema a experiência urbana.

Já no terceiro módulo da disciplina - "Etnografia e desenho" - , voltamo-nos para a contribuição da imagem e do desenho no trabalho antropológico, explorando tal relação através de oficinas e de discussões bibliográficas (Afonso 2004, Galhano 1985, Lagrou 2007, Kuschnir 2011, Leal 2008, Ramos 2004 e 2010, Rosengarten 2010 e Taussig 2009 e 2011). Trata-se de

10 Espero ir cumprindo a missão em textos futuros, de modo a que os interessados tenham acesso aos conteúdos e possam testar todas as atividades por conta própria.

11 A oficina "Caderno feito à mão" foi também a que ganhou o ranking das oficinas que mais contribuíram para o curso, conforme a avaliação final dos alunos. Para um aprofundamento deste debate, ver o já citado Taussig (2011) e Gunn (2009, referência que agradeço à Zoy Anastassakis). Também vale a pena lembrar que a produção de um objeto é prova da "habilidade artesanal" adquirida pelo artífice, fonte de "orgulho pelo próprio trabalho", conforme aponta Sennet (2009:328).

12 Como desdobramentos dessa parceria, criamos em 2013 o Laboratório de Design e Antropologia (parceria Esdi-UERJ e LAU/IFCS/UFRJ) e demos apoio à realização do I Seminário A Criança e sua Participação na Cidade (organizado pelo Cecip no IFCS/UFRJ). 
um tema-chave da pesquisa que venho desenvolvendo ${ }^{13}$, e gostaria de destacar o papel didático de algumas das oficinas oferecidas nesse módulo e sua repercussão juntos aos alunos.

Foi especialmente rica a participação das professoras Andréa Barbosa (Grupo de Estudos Visuais e Urbanos - Visurb, Unifesp) e Els Lagrou (Núcleo de Arte, Imagem e Pesquisa Etnológica - Naipe, IFCS/UFRJ), ambas voltadas para o processo de aprender a ver e conhecer por meio de imagens. Não por acaso Andréa começou sua fala escrevendo no quadro as palavras ver, olhar e enxergar. Através de imagens projetadas, explorou a transição entre essas competências: do ato físico de ver ao olhar como fruto de um aprendizado social carregado de filtros culturais, chegando-se finalmente à possibilidade de enxergar como uma abordagem analítica do mundo (Barbosa, 2012a). ${ }^{14} \mathrm{Na}$ sua oficina, os alunos experimentaram intervir com desenhos e colagens em fotografias feitas pelos colegas, exercitando nesse diálogo novas experiências criativas, ao mesmo tempo em que revisitavam alguns dos pontos explorados em exercícios anteriores, como os da autoria, do deslocamento contexto/ figura e da diversidade de significados dados por diferentes leituras e fabricações de uma imagem. Ao desenhar sobre uma foto, experimentaram, como lembra Massironi (2010:69), a noção de que essa representação gráfica é uma interpretação/codificação resultante de uma "multiplicidade de escolhas".

Els Lagrou retomou a ideia de que "fazer algo é um meio de descobrir certas lógicas que você não conseguiria se só observasse". Através de suas memórias como etnógrafa entre os Kaxinawa, contou-nos que foi pelo processo de aprender a desenhar seus grafismos que teve acesso aos conceitos-chave relacionados à imagem na cosmologia do grupo (Lagrou 2007). Através de fotografias e desenhos projetados, pudemos compreender as diferenças entre kene, dami e yuxin - termos nativos que remetem respectivamente à escrita (ou grafismo), à figura e à fotografia-filmagem ("o que captura a alma”). Mas, como a própria Els relatou, não é possível aprender o que significam esses termos apenas no plano teórico: "Tudo isso eu aprendi desenhando", diz ela. Durante o campo, foi preciso errar, tentar e treinar para adquirir a capacidade de perceber o sentido e as sutilezas dos traçados Kaxinawa e de sua relação com o corpo. "O desafio é você manter a distância entre linhas e, portanto, a coerência do desenho num suporte que é extremamente desigual”, explica Els. É a partir daí que se torna possível perceber a conexão entre o grafismo e as concepções nativas de feminino e masculino.

Nesta oficina, aprendemos que o desenho, para os Kaxinawa, é "uma malha que abre ou fecha a pele, fazendo o intercâmbio com aquilo que é interior e aquilo que é exterior" (Els). A pintura não visa a realçar os traços naturais do rosto, mas sim desestruturar e transformar. Para a parte prática utilizamos maquiagem teatral no lugar dos materiais nativos (jenipapo/preto e urucum/vermelho). Ao começar fazendo uma base vermelha na pele, aprendemos (errando) que uma cor forte demais seria de gosto duvidoso, uma vez que esse tipo de tintura está associado aos Kulina, inimigos dos Kaxinawa. Os traçados foram sendo feitos pelos próprios alunos uns nos outros, a partir de diferentes grafismos desenhados por Els no quadro e depois no meu próprio rosto, como demonstração.

13 Ver Gama e Kuschnir (no prelo), como primeiro esboço sobre o tema.

14 Podemos remeter aqui também às considerações de Rouanet sobre o olhar iluminista que, na Encyclopédie, ganha a indicação: "não se vê sempre o que se olha, mas se olha sempre o que se vê" (Rouanet 1988:126). O papel da ilustração nessa obra é também um tema de destaque em Sennet (2009). 

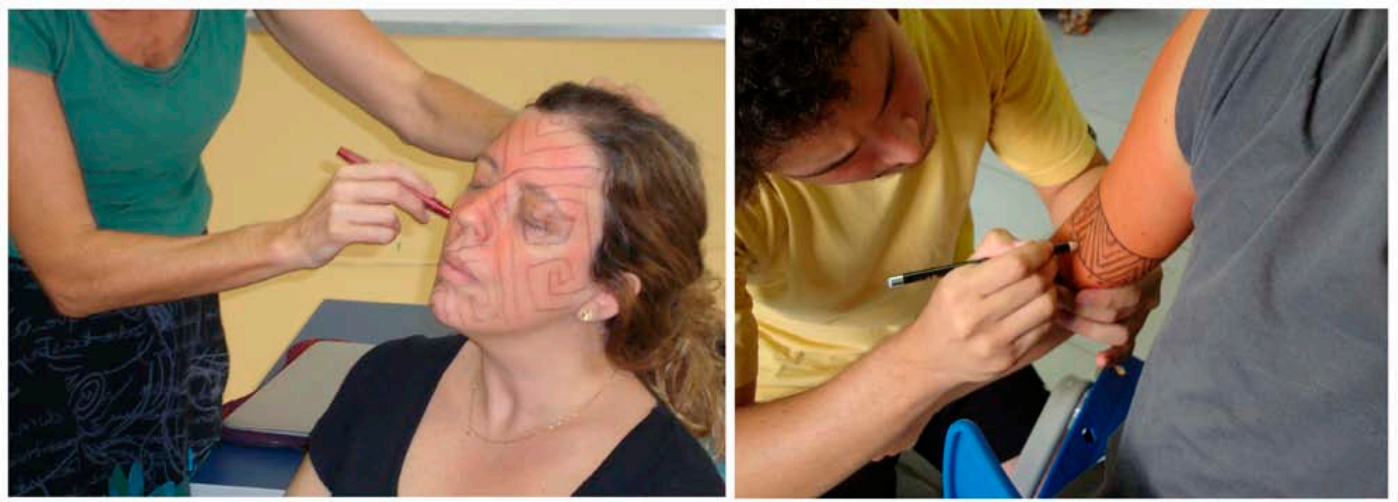

Foi opinião unânime na turma que ambas as oficinas contribuíram para complexificar sua compreensão das imagens, ampliando o potencial de produção do conhecimento trazido tanto pelas formas de ver como pelos modos de fazer/ desenhar. Com objetivos semelhantes fizemos visitas em grupo ao ateliê de Carlos Vergara e à exposição do (já falecido) Newton Rezende (no Centro Municipal de Arte Hélio Oiticica). No primeiro caso, tratou-se principalmente de uma visita entremeada pela excelente conversa com o artista, tendo como foco seu processo de pesquisa por monotipias e outros modos de produção de imagens - processo muito instigado pelo tema da vida urbana e das relações humanas.

$\mathrm{Na}$ segunda experiência tínhamos dois propósitos: (i) desenhar ao longo do caminho do IFCS até a exposição (cerca de 700 metros apenas), "protegidos" pelo fato de estarmos em grupo; e (ii) exercitar o olhar através da tarefa de redesenhar em nossos cadernos partes da obra de Rezende, também com foco na vida urbana. Era para ser um simples exercício, mas se tornou, didaticamente, um ponto de inflexão importante no curso. Todos os alunos escreveram avaliações entusiasmadas, felizes com o fato de terem conseguido, pela primeira vez, ver e registrar o espaço conhecido das ruas com "outros olhos". Muitos também relataram a sensação de que novas camadas de informação foram surgindo nas obras expostas à medida que as desenhavam. Um aluno, por exemplo, relatou: "Escolhi um quadro, mas só depois de começar a desenhá-lo é que percebi que havia ali a imagem de uma gaiola com um pássaro dentro. Estava invisível antes!"15

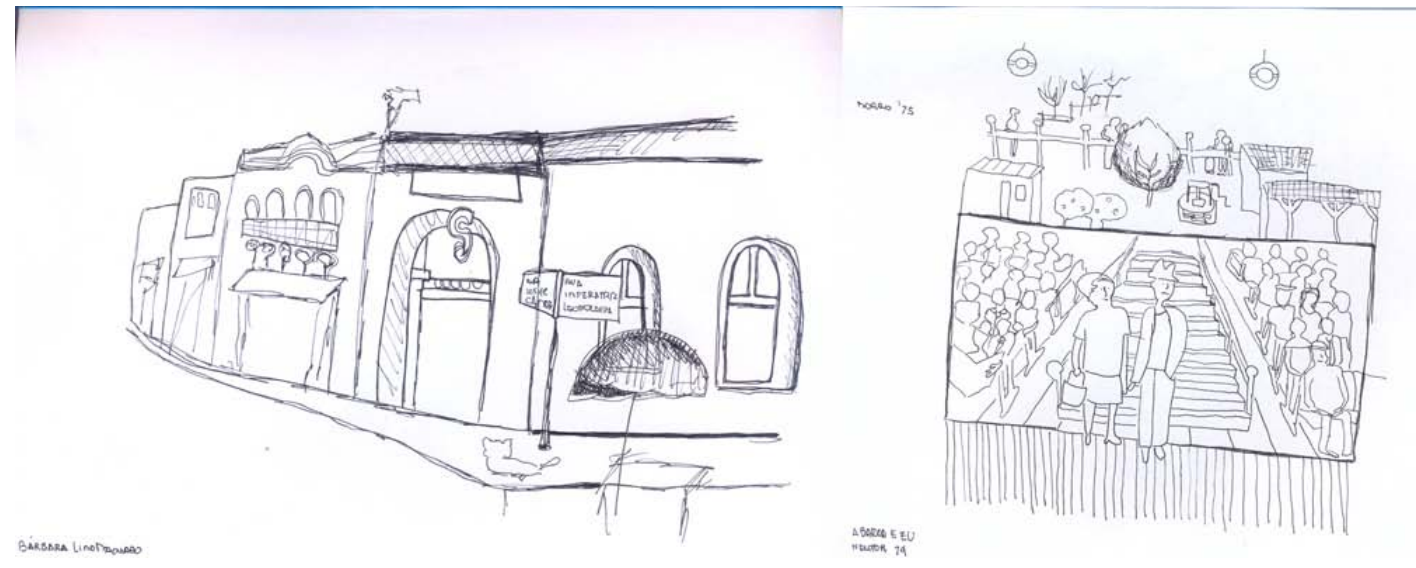

Desenhos da aluna Bárbara Lima Machado

15 Lembro aqui como foi importante o debate em aula sobre visibilidade e invisibilidade na pesquisa urbana através da leitura de Baptista e Nunes (2010). 
Foram nessa direção os demais exercícios e oficinas propostas no curso. Isto é, tiveram por objetivo estimular a realização de pesquisas de campo que utilizassem o desenho como ferramenta de observação e diálogo com o universo pesquisado.

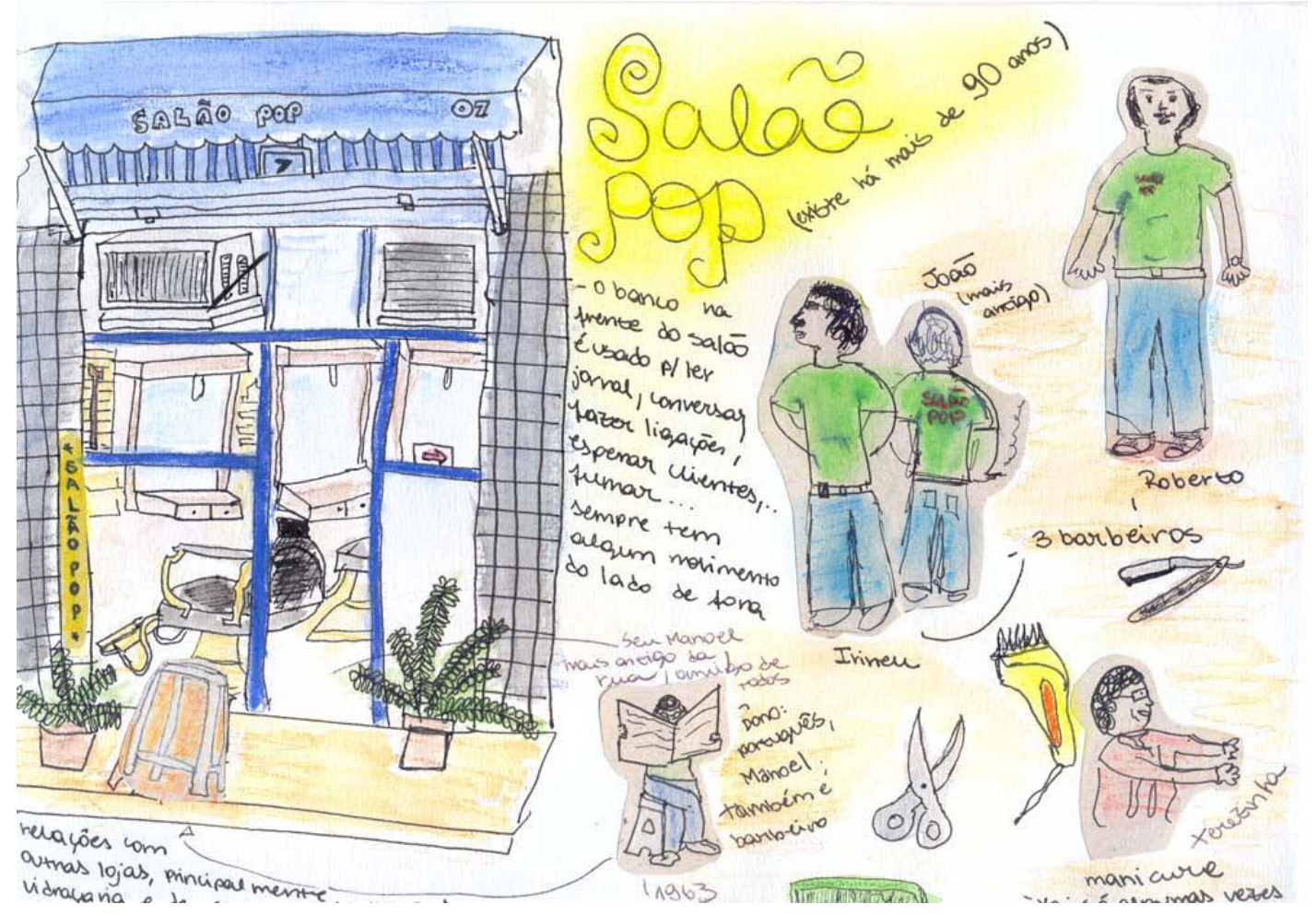

Desenho da aluna Rosa Richter

$\mathrm{Na}$ análise que fizemos sobre os trabalhos finais compostos por textos e desenhos (ver imagem acima), pudemos constatar o quanto as habilidades conquistadas geraram desdobramentos positivos para os pesquisadores (Gama e Kuschnir, no prelo). O desenho foi apontado como um excelente "disparador de conversas" entre antropólogos e seus interlocutores. Abrir o caderno e compartilhar imagens no momento em que são produzidas revelou-se um convite ao diálogo um contraste com situações em que uma câmara foi tratada com desconfiança e afastamento. Os alunos constataram também que o ato de desenhar fez com que ficassem por mais tempo e com mais calma e paciência no campo. O caderno e os materiais foram, além disso, objetos de apoio que deixaram os pesquisadores menos solitários e desconfortáveis naquelas situações tão frequentes na pesquisa etnográfica — situações em que aparentemente "não há nada para fazer" (Taussig 2009); ou, dito de outra forma, o próprio ato de desenhar tornou-se "algo a fazer": um modo de observar e registrar dados, a partir do qual informações não apenas visuais, mas de todas as ordens, se tornam mais acessíveis. Foi consensual a conclusão de que o objetivo não era produzir uma documentação de artefatos (Leal, 2008). O desenho trazia novos modos e novas coisas a ver e registrar, operando também como um "catalizador de memórias" das relações travadas em campo (Ramos 2010:31 e Afonso 2004:76). Os registros gráficos apresentam ainda um ganho para o potencial de comunicação dos resultados da pesquisa, permitindo, como defendeu Velho (2012), que os dados produzidos pelo antropólogo não fiquem confinados aos especialis- 
tas, mas sejam testados, revistos e confrontados. ${ }^{16}$

Vemos assim que, para a antropologia, são muitas as potencialidades do desenho etnográfico e do uso das imagens em campo, como apontaram Afonso (1994), Ramos (2004 e 2010) e Taussig (2009 e 2011), entre outros. ${ }^{17}$ Podemos, portanto, responder positivamente às perguntas iniciais deste texto: aprender a desenhar pode contribuir positivamente para o ensino da antropologia e também para a produção de conhecimento etnográfico. E, sim, um aluno de graduação em Ciências Sociais pode não apenas aprender a desenhar, como aprender novas formas de ver e conhecer o mundo a partir desse processo de aprendizado.

Foi minha intenção também mostrar que a sala de aula "precisa transformar-se cada vez mais em laboratório, e ser cada vez menos auditório", conforme defende F. Becker (2008), retomando os conceitos de Jean Piaget. Já estão mais do que demonstrados o valor de se "aprender a aprender" e a conexão positiva entre o processo de aprendizado e as atividades práticas/lúdicas. Piaget consagrou-se através da demonstração de que os sujeitos aprendem de forma mais sólida quando se apropriam ativamente dos conhecimentos, e não quando são tratados como meros receptáculos a ser preenchidos de conteúdos (Becker 2008). É interessante explorar tais potencialidades em diálogo com a obra de Vygotsky (e com seus desenvolvimentos posteriores), que concebe a aprendizagem como um processo interacional, valorizando o diálogo como um caminho fértil para a produção de significados. Para Vygotsky, como afirma Nóbrega (2003:57), “o aluno passou a ser visto como agente ativo na construção do conhecimento, e teve sua presença sócio-historicamente valorizada dentro do contexto maior de sala de aula". ${ }^{18}$

Durante o curso, apresentei exercícios, técnicas e conteúdos, mas meu objetivo principal era transformar as "aulas" em espaços de experimentação e pesquisa compartilhados. Como afirmei acima, a disciplina surgiu da necessidade de "inventar nativos" para uma investigação sobre desenho. Por isso, tive a permanente preocupação em escutar e dialogar com os alunos, que tomei como interlocutores da pesquisa. Concordo com Oliveira (2000:30) quando este valoriza o "crescente reconhecimento da pluralidade de vozes que compõem a cena e investigação etnográfica", chamando atenção para o fato de que "essas vozes têm de ser distinguidas e jamais caladas". Assim, continua o autor, o bom texto (e poderíamos dizer aqui: a boa investigação) etnográfico(a) é aquele(a) que deixa evidentes as condições de sua produção e de sua obtenção dos dados, mas também os horizontes teóricos com que dialoga, num reconhecimento da sua “intersubjetividade" (Oliveira 2000:31).

Não resisto à tentação, portanto, de terminar este texto com a expressão dos próprios alunos sobre o curso em sua avaliação final. Dos 26 inscritos e dois ouvintes, os vinte que preencheram o questionário responderam positivamente à pergunta: "A disciplina contribuiu para a sua prática como pesquisador?" Todos os aspectos já destacados ao longo deste texto foram mencionados nas respostas. Mas um dos comentários me emocionou de forma particular, por

16 É especialmente rica a discussão da "intercultural ekphrasis", como esse tema está definido em Ramos (2004). Sobre o potencial desse diálogo, construído através das imagens, fotos e filmes, ver também Peixoto (2012).

17 Ver por exemplo, além dos trabalhos já citados, Leal (2008), Newman (1998); e Garavaglia e Menna (1998). 18 A ideia de aprender fazendo foi valorizada recentemente por Ingold em Making (2013). Embora considere várias de suas reflexões muito relevantes, optei aqui por não travar um diálogo mais direto com essa obra, pois eu precisaria de espaço (neste artigo já longo) para demonstrar porque discordo de suas definições ontológicas acerca do desenho (e da antropologia). Prefiro, como afirmou Gell (2009:252) basear-me na ideia de que "nada pode ser decidido antecipadamente" a respeito da natureza dos objetos (e portanto, dos desenhos), optando por tomar cada linha, imagem ou a própria antropologia como uma busca de sentido no contexto das relações sociais. 
dizer que, além de bem-sucedido, o curso aproximou os conceitos de observação no desenho e na antropologia, e foi sobretudo "um lugar de subversão e de experimentação". Era exatamente aí que eu queria chegar.

\section{REFERÊNCIAS}

Afonso, Ana. 2004. "New graphics for old stories: representation of local memories through drawings." Pp. 72-89 in Working Images: Visual Research and Representation in Ethnography, organizado por S. Pink, L. Kürti e A. I. Afonso. London/New York: Routledge.

Baptista, Luís Vicente e João Pedro Nunes. 2010. "Lisboa invisível. Reflexões sobre o trabalho de desocultação das microdinâmicas metropolitanas." Pp. 53-74, in Portugal Invisivel, organizado por A. Dornelas, L. Oliveira, L. Veloso e M. D. Guerreiro. Lisboa: Mundos Sociais.

Barbosa, Ana Mae (Org.). 2011. Ensino da arte: memória e história. São Paulo: Perspectiva.

Barbosa, Andrea. 2012a. "Ver, olhar e enxergar a cidade de São Paulo através das imagens." Pp. 31-44 in São Paulo Cidade Azul: ensaios sobre as imagens. São Paulo: Alameda.

. 2012b. "Pimentas nos olhos não é refresco: espaço, imagem e memória na experiência vivida por jovens moradores de um bairro 'periférico' de Guarulhos, São Paulo [Foto-ensaio].” Cadernos de Arte e Antropologia, 2:103-110. (Disponível em http://goo.gl/0GPHus).

Barthes, Roland. 1990. "A mensagem fotográfica.” Pp. 299-316 in Teoria da Comunicação de Massa. Rio de Janeiro: Paz e Terra.

Becker, Fernando. 2008. "A escola como laboratório e não auditório - Entrevista a Márcia Junges e Patrícia Fachin." Revista do Instituto Humanitas - Unisinos, VIII (281). (Disponível em http://goo.g1/axvV2Z).

Brookes, Mona. 1996. Drawing with children. New York: J P Tarcher/Putnam.

Edwards, Betty. 2001 [1979]. Desenhando com o lado direito do cérebro. Rio de Janeiro: Ediouro.

Feldman-bianco, Bela e Miriam L. Moreira Leite (Orgs.). 1988. Desafios da imagem. Fotografia, iconografia e video nas Ciências Sociais. Campinas: Papirus.

Galhano, Fernando. 1985. Desenho etnográfico de Fernando Galbano. Lisboa: Instituto Nacional de Investigação Científica/Centro de Estudos de Etnologia.

Gama, Pedro Ferraz e Karina Kuschnir. (no prelo). "Contribuições do desenho para a pesquisa antropológica." Revista do CFCH, UFRJ.

Garavaglia, Magdalena V.e Rosana B. Menna 1998. "Sobre el uso de imágenes gráficas en la investigación antropológica. Un acercamiento a la Antropología Visual”. 1er Congreso Virtual de Antropología y Arqueología. (Disponível em http://goo.g1/foW98G).

Gell, Alfred. 2009. "Definição do problema: a necessidade de uma antropologia da arte”. Revista Poiésis 14:245-261.

Gregory, Danny. 2003. Everyday matters: a memoir. New York: Hyperion. 2006. The creative license: giving yourself permission to be the artist you truly are. New York: Hyperion.

Grubits, Sonia. 2003. "A casa: cultura e sociedade na expressão do desenho infantil”. Psicologia em Estudo 8:97-105, n. especial, Maringá. (Disponível em http://goo.gl/1btLD6).

Gunn, Wendy (ed.). 2009. Fieldnotes and Sketchbooks - Challenging the Boundaries between Descriptions and Processes of Describing. Frankfurt: Peter Lang.

Ingold, Tim. 2013. Making - Antbropology, archaeology, art and architecture. London: Routledge. 
Kuschnir, Karina. 2011. "Drawing the city - a proposal for an ethnographic study in Rio de Janeiro." Vibrant - Virtual Brazilian Antbropology, 8(2): 609-642. (Disponível em http:// goo.gl/66GqES)

. 2012. “Desenhando cidades." Revista Sociologia E Antropologia, 2(4): 295-314.

(Disponível em http://goo.gl/gq6ZnU)

Lagrou, Els. 2007. A Fluidez da Forma. Arte, alteridade e agência em uma sociedade amazônica (Kaxinawa, Acre). Rio de Janeiro: Topbooks.

2009. Arte indigena brasileira. Belo Horizonte: ComArte.

Leal, João. 2008. "Retratos do povo: etnografia portuguesa e imagem.” Pp. 117-145 in O visual e o quotidiano, organizado por J. Machado Pais, C. Carvalho e N. M. Gusmão. Lisboa: Imprensa de Ciências Sociais.

Magnani, José Guilherme C. 2002. "De perto e de dentro: notas para uma etnografia urbana." Revista Brasileira de Ciências Sociais, 17 (49): 11-29. (Disponível em http://goo.gl/iriy4G)

Massironi, Manfredo. 2010 [1982]. Ver pelo desenho: aspectos técnicos, cognitivos, comunicativos. Lisboa: Edições 70.

Newman, Deena.1998. "Prophecies, Police Reports, Cartoons and Other Ethnographic Rumors in Addis Ababa." Etnofoor XI(2):83-110.

Niemeyer, Ana Maria. 1998. "Indicando caminhos: mapas como suporte na orientação espacial e como instrumento no ensino de antropologia." Pp. 11-40 in Além dos territórios: para um diálogo entre a etnologia indígena, os estudos rurais e os estudos urbanos, organizado por A. Niemeyer e E. Godoy. Campinas: Mercado de Letras.

Oliveira, Roberto Cardoso. 2000. "O trabalho do antropólogo: olhar, ouvir, escrever.” Pp. 17-35 in O trabalho do antropólogo (2a . edição revista.) São Paulo: Unesp.

Peirano, Mariza. 1992. "A favor da etnografia." Série Antropologia 130. Brasília: UnB. (Disponível em http://goo.gl/Z8171z)

Peixoto, Clarice E. 2012. "The Photo in the Film: Public and private collections in video-portrait." Vibrant - Virtual Brazilian Anthropology 9(2). (Disponível em http://goo.gl/ eN1LNK)

Ramos, Manoel João. 2004. "Drawing the lines: the limitations of intercultural ekphrasis." Pp. 147-161 in Working Images: Visual Research and Representation in Ethnography, organizado por S. Pink, L. Kürti e A. I. Afonso. London/New York: Routledge. . 2010. Histórias etiopes. Lisboa: Tinta da China.

Reichenstein, Oliver. 2013. “Learning to see.” Information Architects Blog. (Disponível em http:// ia.net/blog/learning-to-see/)

Rosengarten, Ruth. 2010. "Passar por aí, parar, continuar a andar: desenho urbano em contexto." Pp. 24-40 in Urban Sketchers em Lisboa: desenhando a cidade. Lisboa: Quimera.

Rouanet, Sergio Paulo. 1988. “O olhar iluminista.” Pp. 125-148 in O olhar, organizado por Adauto Novaes. São Paulo: Companhia das Letras.

Samain, Etienne (org.). 2012. Como pensam as imagens. Campinas: Unicamp.

Salavisa, Eduardo (Coord.) 2008. Diários de viagem: desenhos do quotidiano - 35 autores contemporâneos. Lisboa: Quimera.

Sennet, Richard. 2009. O artifice. Rio de Janeiro: Record.

Taussig, Michael. 2009. "What do drawings want?." Culture, Theory and Critique 50(2): 263274.

2011. I swear I saw this: Drawings in Fieldwork Notebooks, Namely My Own. Chicago: University of Chicago Press.

Turner, Victor. 2005 [1963]. "A classificação das cores no ritual Ndembu: um problema de classificação primitiva." Pp. 95-135 in Floresta de Simbolos. Aspectos do Ritual Ndembu. Niterói: 


\section{EdUFF.}

Velho, Gilberto. 2013 [1978], "Observando o familiar." Pp. 69-79 in Um antropólogo na cidade: ensaios de antropologia urbana, organizado por H. Vianna, K. Kuschnir e C. Castro. Rio de Janeiro: Zahar.

\section{TEACHING ANTHROPOLOGISTS TO DRAW: A DIDACTIC RESEARCH EXPERIENCE}

In this article I present the results of a teaching experience called "Laboratory of Anthropology and Drawing", which proposes drawing as an important tool for ethnographic research. Students with no prior training in the area were introduced to drawing as a way of knowing the world. During the workshops, conventional conceptions of drawing were deconstructed and new narrative forms encountered, which graphically evoked ideas, encounters, conversations, observations and insights into social life. During the exercises, we dealt with: a) training researchers to dialogue and interact with their research universe, and b) the collection of data and the communication of research results. The experience continued outside the classroom to explore public spaces in the city of Rio de Janeiro, trying to understand the city and the multitude of possible points of view offered by an urban space. The analysis of the material produced aimed to address central issues of the praxis of anthropological research, exploring questions and answers that emerge out of the teaching of drawing and the construction of pictorial narratives on (and about) fieldwork.

Keywords: anthropology, drawing, teaching, ethnography

Recebido em: 2014-03-07

Aceito em: 2014-07-03 